\title{
Release of resource constraints allows greater carbon allocation to secondary metabolites and storage in winter wheat
}

\author{
Jianbei Huang ${ }^{1}$, Almuth Hammerbacher ${ }^{2,3}$, Lenka Forkelová ${ }^{1}$ \& Henrik Hartmann ${ }^{1}$ \\ ${ }^{1}$ Max Planck Institute for Biogeochemistry, Hans-Knöll-Str. 10, 07745 Jena, Germany, \\ ${ }^{2}$ Max Planck Institute for Chemical Ecology, Hans-Knöll-Str. 8, 07745 Jena, Germany and \\ ${ }^{3}$ Department of Microbiology and Plant Pathology, Forestry and Agricultural Biotechnology Institute, University \\ of Pretoria, Private Bag X20, Pretoria 0028, South Africa
}

\begin{abstract}
The atmospheric $\mathrm{CO}_{2}$ concentration $\left(\left[\mathrm{CO}_{2}\right]\right)$ is rapidly increasing, and this may have substantial impact on how plants allocate metabolic resources. A thorough understanding of allocation priorities can be achieved by modifying $\left[\mathrm{CO}_{2}\right]$ over a large gradient, including low $\left[\mathrm{CO}_{2}\right]$, thereby altering plant carbon $(\mathrm{C})$ availability. Such information is of critical importance for understanding plant responses to global environmental change. We quantified the percentage of daytime whole-plant net assimilation (A) allocated to nighttime respiration (R), structural growth (SG), nonstructural carbohydrates (NSC) and secondary metabolites (SMs) during 8 weeks of vegetative growth in winter wheat (Triticum aestivum) growing at low, ambient and elevated $\left[\mathrm{CO}_{2}\right](170,390$ and $680 \mathrm{ppm})$. R/A remained relatively constant over a large gradient of $\left[\mathrm{CO}_{2}\right]$. However, with increasing $\mathrm{C}$ availability, the fraction of assimilation allocated to biomass (SG + NSC + SMs), in particular NSC and SMs, increased. At low $\left[\mathrm{CO}_{2}\right]$, biomass and NSC increased in leaves but decreased in stems and roots, which may help plants achieve a functional equilibrium, that is, overcome the most severe resource limitation. These results reveal that increasing $\mathrm{C}$ availability from rising $\left[\mathrm{CO}_{2}\right]$ releases allocation constraints, thereby allowing greater investment into longterm survival in the form of NSC and SMs.
\end{abstract}

\section{Introduction}

For more than 40 years, the control mechanisms of whole-plant carbon (C) allocation have been of central interest to plant scientists (Mooney, 1972). Plants fix $\mathrm{CO}_{2}$ from the atmosphere and partition the resulting photosynthetic products (carbohydrates) among several uses, including growth of structural biomass, synthesis of secondary metabolites and metabolic processes like respiration and osmoregulation. The atmospheric $\mathrm{CO}_{2}$ concentration $\left(\left[\mathrm{CO}_{2}\right]\right)$ has increased from $170 \mathrm{ppm}$ during glacial periods of the past million years to the current $\sim 400 \mathrm{ppm}$ and is expected to increase up to $430 \mathrm{ppm}$ to $1000 \mathrm{ppm}$ by the year 2100 (Cubasch et al., 2013). However, little is known about how increased $\left[\mathrm{CO}_{2}\right]$ alters partitioning of fixed $\mathrm{C}$ among different sinks or about the processes regulating allocation (Dietze et al., 2014). 
Historically, the regulation of plant $C$ partitioning was thought to be driven by $C$ supply (i.e. source activity), but recent evidence suggests that sink activity may be the main determinant (Fatichi et al., 2014; Korner, 2015). Experiments manipulating source activity via $\left[\mathrm{CO}_{2}\right]$ availability can elucidate the contributions of sources and sinks for whole-plant $C$ allocation (Fatichi et al., 2014). However, such studies are still sparse, not only because of the expense of manipulating $\left[\mathrm{CO}_{2}\right]$ (Gerhart \& Ward, 2010), but also because of challenges in assessing both whole-plant $C$ balance (assimilation minus respiration; $A-R$ ) and how nonrespired $C$ is distributed among sink components, that is, structural growth (SG), nonstructural carbohydrates (NSC), secondary metabolites (SMs) and export (e.g. to rhizosphere symbionts or as volatile organic compounds (VOCs)) (Fig. 1).

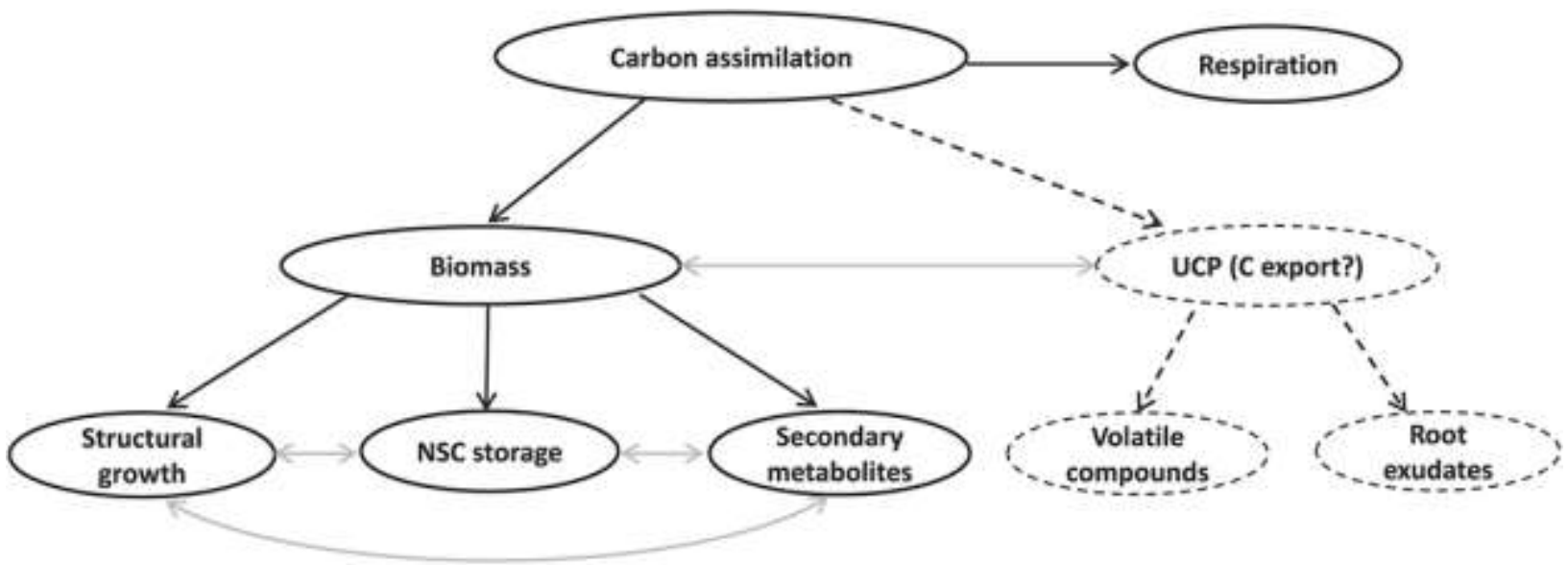

Figure 1. Conceptual model for trade-offs in carbon allocation to functional pools respiration, biomass (structural growth + non-structural carbohydrates (NSC) + secondary metabolites) and an - operationally defined - unaccounted carbon pool (UCP, potentially export to volatile compounds and root exudates). Black solid arrows indicate established (based on literature) carbon flow between pools, while black dashed arrows indicate flows that remain uncertain mainly due to technical difficulties in measuring them. Such flows require further investigation (see Discussion and Outlook sections). Grey solid arrows indicate trade-off situation between different carbon pools, as suggested by growth-defence hypotheses and different carbon storage paradigms.

In many plant species, short-term stimulation of leaf-level photosynthesis by elevated $\left[\mathrm{CO}_{2}\right]$ (Franks et al., 2013; Gerhart \& Ward, 2010) is often associated with down-regulation of photosynthesis in the long term (Lee et al., 2011; Long et al., 2004). However, leaf-level net photosynthetic rates cannot be directly scaled up to whole-plant assimilation for a number of reasons. For example, leaf-level assimilation measurements are usually done under ideal light and temperature conditions (Kirschbaum, 2011) and therefore may overestimate actual assimilation rates. Scaling up from leaf to whole-plant gas exchange also requires parameterization of leaf phenology and light distribution. In addition, photosynthesis in non-leaf tissues (bark, stems) may not scale in the same way as in leaves. Therefore, direct whole-plant assessment of gas exchange is a more suitable method for determining wholeplant responses to different $\left[\mathrm{CO}_{2}\right]$ (Atkin et al., 2007; Boote et al., 2013).

Respiration $(R)$ is an essential plant functional process providing energy and metabolic intermediates needed for photosynthesis, which in turn provides substrates for R. Some studies have reported that whole-plant R may account for up to $30-50 \%$ of the gross 
photosynthetic $\mathrm{CO}_{2}$ uptake in herbaceous plants, and due to the interdependency of these processes this proportion remains relatively constant under a gradient of environmental conditions (Atkin et al., 2007; Gifford, 1995; Pons \& Poorter, 2014). In our study, we measured net $\mathrm{C}$ assimilation; during the day-time, this is the difference between $\mathrm{A}$ and $\mathrm{R}$; at night, as there is no assimilation it represents only $\mathrm{R}$.

Species adapted to low resource availability have intrinsically lower growth rates than species adapted to high resource availability (Endara \& Coley, 2011). Therefore, modern plants adapted to current $\left[\mathrm{CO}_{2}\right]$ may not be able to utilize higher $\left[\mathrm{CO}_{2}\right]$ assimilation for growth (Tissue \& Lewis, 2012). Under elevated $\left[\mathrm{CO}_{2}\right]$, growth may also be constrained by environment factors such as water and nutrients (Kirschbaum, 2011; Palacio et al., 2014). A $30-40 \%$ increase in leaf-level photosynthesis leads only to a $10 \%$ increase in relative growth rate (reviewed in Kirschbaum, 2011). By contrast, plants grown at low $\left[\mathrm{CO}_{2}\right]$ may fully utilize all assimilated $\mathrm{C}$ for growth while concurrently reduce $\mathrm{C}$ loss to exports, particularly in the form of VOCs and rhizodeposits, at least when nutrients are provided and freely accessible (Fig. 1).

Plants maintain large pools of NSC compounds that can enhance plant survival during stresses (Dietze et al., 2014; Hartmann \& Trumbore, 2016), and strategies of C allocation to NSC pools have been discussed for more than 25 years (Chapin et al., 1990). NSC pools have often been considered as reservoirs filled with $C$ that is available in excess of demand (accumulation of NSC) (Palacio et al., 2014). However, an alternate model suggests that plants allocate $C$ to NSC to ensure future $C$ availability even at the expense of other $C$ sinks such as SG (reviewed in Dietze et al., 2014; Wiley \& Helliker, 2012). Recent studies provide evidence of $C$ allocation to NSC storage even in half defoliated Quercus velutina saplings (Wiley et al., 2013) and in Picea abies saplings grown under low $\left[\mathrm{CO}_{2}\right]$ (Hartmann et al., 2015).

Plants may allocate a substantial proportion of available C to SMs that play important roles in biotic and abiotic interactions (Neilson et al., 2013). For example, glucosinolates are one of the major classes of defensive SMs (Halkier \& Gershenzon, 2006), and up to $15 \%$ of total photosynthetic energy may be required for glucosinolate production in Arabidopsis thaliana (Bekaert et al., 2012). This large $C$ investment, however, may divert resources away from other metabolic processes. The growth-differentiation balance hypothesis (GDBH) (Herms \& Mattson, 1992) suggests that allocation to SMs is driven by $C$ availability in excess of growth demand. Under ideal conditions, this trade-off may be less constrained, and plants can grow larger leaf canopies with higher SM production than under resource limitation. In support of this hypothesis, C-based SMs increased under elevated $\left[\mathrm{CO}_{2}\right]$ (Robinson et al., 2012), while O'Neill et al. (2010) found that only quercetin triglycoside increased but genistein decreased in soybean (Glycine max) foliage.

Trade-off situations in allocation occur not only across functional sinks but also across plant tissues and organs. Plants are thought to invest $\mathrm{C}$ preferentially into tissues that are responsible for acquiring the most limiting resource; this is termed 'functional equilibrium'. Such an optimal allocation strategy has been observed in biomass partitioning under low $\left[\mathrm{CO}_{2}\right]$ where plants allocated proportionally more $\mathrm{C}$ to above-ground than to belowground 
tissues (Poorter et al., 2012; Temme et al., 2013; Zhang et al., 2015), but data on the partitioning to different functional sinks, like NSC (Hartmann et al., 2015) and SMs, and across different plant tissues and organs are still very sparse.

The objective of this study was to investigate $C$ allocation tradeoffs in winter wheat (Triticum aestivum L.) during the vegetative growth phase. Previous studies have shown that elevated $\left[\mathrm{CO}_{2}\right]$ will cause photosynthetic acclimation of wheat plants (Aranjuelo et al., 2011; Aranjuelo et al., 2015), but much less is known about allocation priorities across functional sinks under these conditions. Such priorities can be deduced from assessments of allocation patterns along a plant $\mathrm{C}$ availability gradient, including low [ $\left.\mathrm{CO}_{2}\right]$ (Hartmann et al., 2015). Although shading may be a much simpler approach for reducing plant $C$ availability, it may also trigger phytochrome-induced growth stimulation (Casal, 2013) and defence suppression (Ballare, 2014), independent of $\mathrm{C}$ availability. Direct manipulations of atmospheric $\left[\mathrm{CO}_{2}\right]$ suffer less from such side effects and allow plants to adjust to $C$ (rather than light) availability.

Because allocation is a continuous process, the whole-plant fluxes ( $A-R$ derived from gas exchange) and pools were monitored over the vegetative growth phase using a unique chamber design implemented in a greenhouse. Supplemental nutrients were applied to the substrate in order to minimize nutrient limitations on plants. Allocation to reproduction (seed production) was purposely excluded in this study because pollination has been shown to be problematic and incomplete in these growth chambers, likely due to light limitation. Changes in primary (NSC, including soluble sugars, starch and fructans) and SMs (including flavonoid glycosides and benzoxazinoids) of plant tissues (leaves, stems and roots) were used to partition biomass into SG (SG = Biomass - NSC - SMs) and nonstructural components (NSC and SMs). Specifically, we hypothesized that, with increasing $\left[\mathrm{CO}_{2}\right](170$, 390 and $680 \mathrm{ppm}$ ): (1) the proportion of $C$ allocated to $R$ remains constant but decreases in biomass (SG + NSC + SMs) (relative to A); (2) NSC and SMs increase while SG decreases; and (3) biomass (SG + NSC + SMs) increases in stems and roots but decreases in leaves, in accordance with the functional equilibrium hypothesis.

\section{Materials and Methods}

\section{Plant material}

A cultivar of winter wheat from a local seed plantation (Bioland Hof Jeebel Biogartenversand, Salzwedel, Germany) adapted to Central Europe was used in our study. On 7 January 2015, seeds were germinated in plates filled with sand and were watered every day. On 13 and 14 January 2015, seedlings of similar height were transplanted into pots (diameter $11 \mathrm{~cm}$, height $24 \mathrm{~cm}$ ) filled with C-free quartz sand. Four pots (12 seedlings per pot) and two pots (10 seedlings per pot) were randomly placed in each plant chamber immediately after transplanting (Fig. 2). We provided the plants with supplemental nutrients by watering pots with a continuous through-flow of a modified Hoagland nutrient solution (Hoagland \& Arnon, 1950) to avoid nutrient limitation (other than C). 


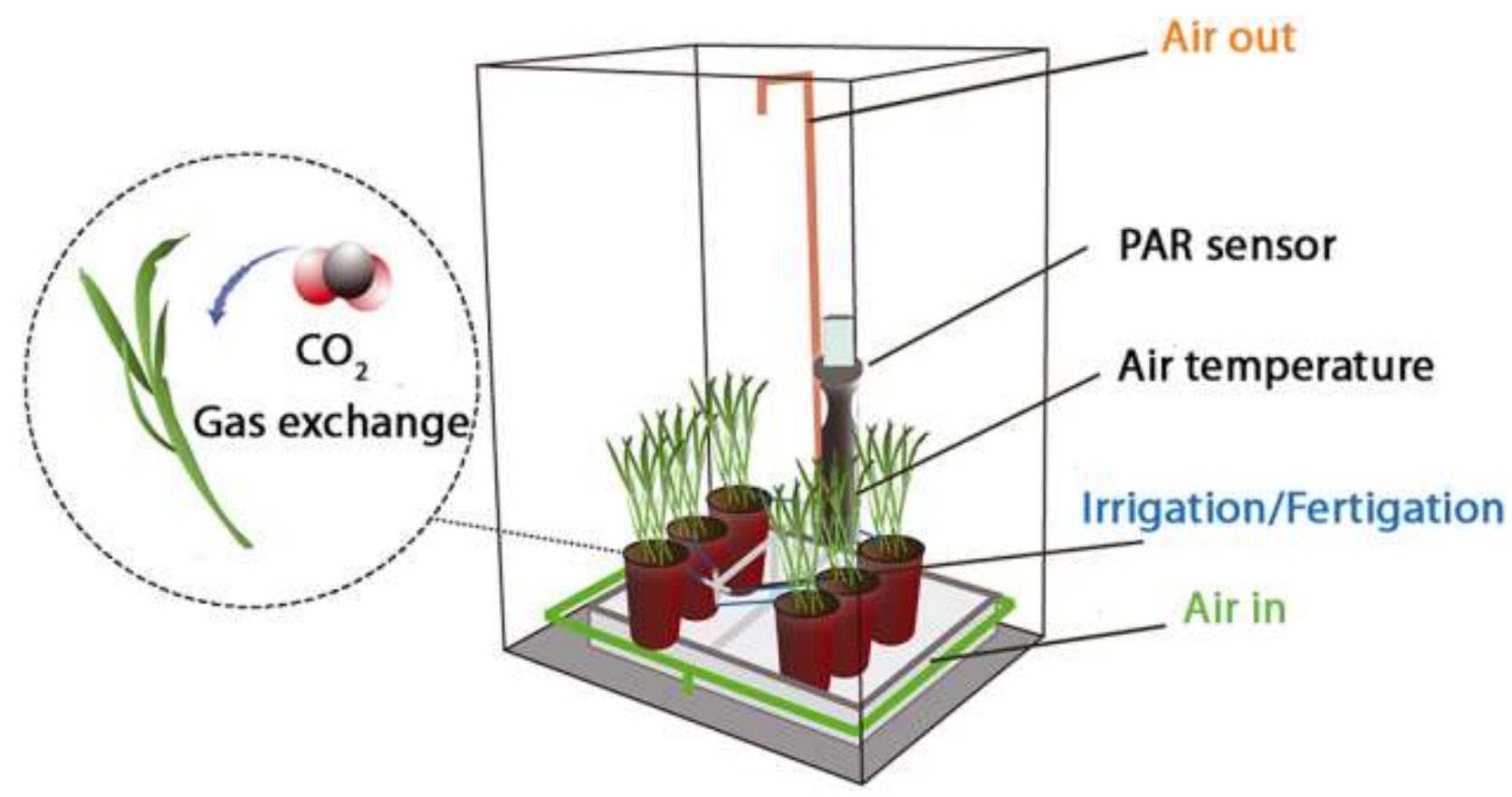

Figure 2. Schematic view of one of the 12 chambers showing the ventilation system and the photosynthetically active radiation (PAR) sensor. Air was flushed continuously through inlet tubing located at the bottom and outlet tubing at the top of the chamber. Four pots (12 seedlings per pot) and two pots (10 seedlings per pot) were randomly placed in each plant chamber. Note that only pots containing 12 seedlings were harvested. Supplemental nutrients were provided by watering the pots with a continuous through-flow of a modified Hoagland nutrient solution.

\section{Growth chambers}

Twelve aquarium-style glass chambers ( $80 \mathrm{~cm}$ high $\times 75 \mathrm{~cm}$ long $\times 45 \mathrm{~cm}$ wide) were used to isolate the atmosphere around the plants and allowed controlling $\left[\mathrm{CO}_{2}\right]$ (Fig. 2). Chambers were placed on a greenhouse table covered with closed-cell rubber foam mats made of ethylene propylene diene monomer for airtight sealing (as in Hartmann et al. (2013)). Air in the chambers was flushed continuously at a flow rate of $141 \mathrm{~min}^{-1}$ through inlet tubing located at the bottom and outlet tubing at the top of the chamber. The $\left[\mathrm{CO}_{2}\right]$ of incoming air was controlled by first scrubbing all $\mathrm{CO}_{2}$ from atmospheric air using a molecular sieve and then adding pure $\mathrm{CO}_{2}$ from a gas tank (Schnyder, 1992). The $\mathrm{CO}_{2}$-free air was separated into three air circuits (four chambers per circuit); in each circuit, $\left[\mathrm{CO}_{2}\right]$ was measured sequentially with a Vaisala (GMP 343) at intervals of $10 \mathrm{~min}$, using a custom-built switching valve controlled by a micro-logger (Campbell $\left.{ }^{\oplus} \mathrm{CR} 1000\right)$. Measured $\left[\mathrm{CO}_{2}\right]$ were compared against pre-set values (170, 390 and $680 \mathrm{ppm}$, respectively), and, if required, $\mathrm{CO}_{2}$ supply to the airstream was adjusted via mass flow controllers to maintain target $\left[\mathrm{CO}_{2}\right]$ levels. To minimize differences in light levels, treatments were randomly assigned on the table, and three of four chambers per treatment were used to grow plants while the other one was used to monitor $\left[\mathrm{CO}_{2}\right]$ directly in the chamber.

In each chamber, air temperature and photosynthetic photon flux density were monitored continuously (see Hartmann et al., 2013). During the day, average temperatures increased from ca. $12{ }^{\circ} \mathrm{C}$ at $6: 30$ (local time) to ca. $20-24^{\circ} \mathrm{C}$ in the afternoon, and then decreased to 
ca. $16.5^{\circ} \mathrm{C}$ at $22: 00$. During the night, air temperature declined from ca. 16 to $11^{\circ} \mathrm{C}$. All plants were grown in a 16/8 h light/dark regime using supplemental greenhouse lamps (SonT Agro $^{\circledast} 430 \mathrm{~W}$ HPS bulbs, primary light range $=520-610 \mathrm{~nm}$, Philips ${ }^{\circledR}$ Lighting Co., Somerset, NJ, USA). The average daily total photosynthetic photon flux density inside the chambers from 23 January to 20 March was $7.79 \pm 0.92 \mathrm{~mol} \mathrm{~m}^{-2} \mathrm{~d}^{-1}$.

\section{Destructive harvesting and biomass processing}

Allocation priorities likely differ between growth stages of winter wheat (seedling, tillering, stem elongation, flowering and grain filling), and we concentrated on the vegetative growth period (seedling and tillering stage) to rule out the potential confounding effects of developmental stage on plant allocation. According to the growth scale of Zadoks et al. (1974), seedling growth of winter wheat is achieved before the occurrence of nine unfolded leaves on the main shoot. Plants were therefore harvested when three, six and eight leaf sheaths were completely developed, denoted as $3 \mathrm{~L}, 6 \mathrm{~L}$ and $8 \mathrm{~L}$ periods, respectively. For 390 and 680 ppm treatments, this occurred 3, 7 and 9 weeks after transplanting, respectively, while development in the low $\left[\mathrm{CO}_{2}\right]$ treatment was slower, and plants were sampled 3.5, 8 and 10.5 weeks after transplanting. Sampling was always conducted between 16:00 and 21:00. At each sampling, three pots (12 seedlings per pot) from three chambers of each $\left[\mathrm{CO}_{2}\right]$ treatment were destructively harvested. Fresh biomass of whole-plant leaves, stems and roots of each pot were determined, and then all tissues were shock-frozen in liquid nitrogen and stored at $-80^{\circ} \mathrm{C}$, freeze-dried and weighted for dry biomass. Dry tissues were homogenized and ground to fine powder using a ball mill (Retsch ${ }^{\oplus} \mathrm{MM} 400$, Haan, Germany) and stored at $-20^{\circ} \mathrm{C}$ until analysis.

\section{Whole-plant gas exchange}

Gas exchange data were measured with a Picarro ${ }^{\oplus} 2101-i$ (precision $0.01-0.4 \%$, Picarro Inc. Santa Clara, CA, USA) for the first 7 weeks (extending beyond the $6 \mathrm{~L}$ period) under 680,390 and $170 \mathrm{ppm}\left[\mathrm{CO}_{2}\right]$. However, because the Picarro failed after week 7, gas exchange for week 8, 9, 10 and 11 were measured with a Spectronus ${ }^{\circledR}$ FTIR (Fourier transform infrared spectroscopy, Ecotech Pty Ltd., Knoxfield, VIC, Australia) using otherwise the same hardware and the same sequence protocol as mentioned above. Reference gases were used to verify and ensure comparability across devices.

Within $2 \mathrm{~h}$, the $\left[\mathrm{CO}_{2}\right]$ of air leaving the 12 chambers and 6 reference air samples (taken from the air circuit) were measured sequentially at intervals of $6 \mathrm{~min} 40 \mathrm{~s}$, and the sequence was controlled by a micro-logger (Campbell ${ }^{\oplus}$ CR1000) and a custom-built switching valve unit. Transition periods after valve switching were excluded from analysis, and a core period of $3 \mathrm{~min} 20 \mathrm{~s}$ was used to estimate instantaneous whole-plant gas exchange, defined as:

$\Delta\left[\mathrm{CO}_{2}\right]=\frac{\left[\mathrm{CO}_{2}\right]_{\text {non-plant }}-\left[\mathrm{CO}_{2}\right]_{\text {plant }}}{M}$ 
where $\left[\mathrm{CO}_{2}\right]_{\text {non-plant }}$ is the $\left[\mathrm{CO}_{2}\right]$ of outgoing air from the chamber without plants, and $\left[\mathrm{CO}_{2}\right]_{\text {plant }}$ is the $\left[\mathrm{CO}_{2}\right]$ of outgoing air from chambers with plants. $M$ is the number of plants grown in the chamber.

The whole-plant gas exchange rate was assumed to be constant within the $2 \mathrm{~h}$ cycle and whole-plant $C$ flux at hour $j$ was calculated as:

$\mathrm{C}_{i}\left(\mathrm{~g} \mathrm{~h}^{-1}\right)=\frac{\Delta\left[\mathrm{CO}_{2}\right]\left(\mu \mathrm{mol} \mathrm{mol} \mathrm{mon}^{-1}\right) * \operatorname{VFR}\left(1 \mathrm{~min}^{-1}\right) * 60 \mathrm{~min} * 12\left(\mathrm{~g} \mathrm{~mol}^{-1}\right)}{22.4\left(1 \mathrm{~mol}^{-1}\right) * 1000000}$

where VFR is the volumetric flow rates of air going through the chambers, that is, $14 \mathrm{I} \mathrm{min}^{-1}$, and $22.4 \mathrm{I} \mathrm{mol}^{-1}$ is the molar volume of gas at normal conditions. The cumulative daily whole-plant net $\mathrm{C}$ assimilation $\left(\mathrm{A}_{\text {cum_n } n}\right)$ and night-time respiration $\left(\mathrm{R}_{\text {cum_n } n}\right)$ over the duration of the experiment ( $n=$ number of days $d, j=$ hour of day) were then computed using the following equation:

$A_{\text {cum_n }}=\sum_{i=1}^{n} \sum_{j=7}^{22} \mathrm{C}_{j}(3)$
$R_{\text {cum_n }}=\sum_{i=1}^{n} \sum_{j=23}^{24} \mathrm{C}_{j}+\sum_{i=1}^{n} \sum_{j=1}^{06} \mathrm{C}_{j .}$

$A_{\text {cum_n }}$ and $R_{\text {cum_n }}$ between $3 \mathrm{~L}$ and $6 \mathrm{~L}$ were used to calculate the fraction of $C$ allocated to $R$. Whole-plant $A$ and $R$ collected over the last two or three days prior to biomass sampling were averaged for calculations of mass-based (i.e. specific) rates of daily net assimilation and respiration.

While C-free quartz sand was used to avoid any $\mathrm{C}$ input into the system other than from plant photosynthesis, it was technically impossible to sterilize the all components of such a greenhouse facility (air, water, plant material) to a degree that would completely avoid microbial infestation. Hence, microbial respiration of root exudates or litter may be included in the gas exchange measurements. However, given that root exudation (Grayston et al., 1997; Phillips et al., 2009) represents a much smaller $C$ flux than respiration $(<10 \%$ versus 30-50\%) (Atkin et al., 2007; Gifford, 1995; Pons \& Poorter, 2014), gas exchange data represent mainly plant assimilation and respiration (Hartmann et al., 2015; Hartmann et al., 2013).

\section{NSC analysis}

Concentrations of soluble sugars and starch in plant tissues were determined using methods described in Raessler et al. (2010). For soluble sugars, usually $1 \mathrm{ml}$ (or $0.5 \mathrm{ml}$ for small samples) of sterilized water was added to $50 \mathrm{mg}$ (or $10 \mathrm{mg}$ for small samples) dry biomass. The mixture was vortexed, incubated at $65^{\circ} \mathrm{C}$ for $10 \mathrm{~min}$ and then centrifuged at $12000 \mathrm{~g}$ for $10 \mathrm{~min}$. The supernatant was collected and stored on ice, and the remaining pellet was re-extracted twice using the same procedure. The supernatants were pooled and then diluted at a ratio of $1: 20$ (or $1: 8$ for small samples) and stored at $-20^{\circ} \mathrm{C}$. For starch, $50 \mathrm{mg}$ (or $10 \mathrm{mg}$ for small samples) dry biomass were extracted with $0.35 \mathrm{ml}$ (or $0.175 \mathrm{ml}$ for small 
samples) of water and $0.5 \mathrm{ml}$ (or $0.25 \mathrm{ml}$ for small samples) of perchloric acid (52\%). The mixture was vortexed, incubated at $65^{\circ} \mathrm{C}$ for $10 \mathrm{~min}$ and then centrifuged at $12000 \mathrm{~g}$ for $10 \mathrm{~min}$. The supernatant was collected, and the remaining pellet was re-extracted. The supernatants were pooled and then diluted at a ratio of $1: 55$, stored at $-20^{\circ} \mathrm{C}$.

Sucrose, glucose and fructose of both soluble sugars and starch extractions were determined by High-Performance Liquid Chromatography coupled with Pulsed Amperometric Detection (HPLC-PAD), using a Dionex ICS 3000 ion chromatography system equipped with an autosampler (Thermo Fisher $\mathrm{GmbH}$, Idstein, Germany). Starch concentrations were calculated by subtracting glucose and half of the sucrose concentrations in water-soluble extract from glucose concentrations in the hydrolyzed extract then multiplying a conversion factor of 0.9 (Sullivan, 1935). Fructan concentrations were calculated using the same method but with fructose instead of glucose concentrations, given that fructan is one of the most important $\mathrm{C}$ storage compounds in wheat (Pollock \& Cairns, 1991). Total NSC concentrations reported are the sum of soluble sugars, starch and fructans.

\section{SM analysis}

Samples from $680 \mathrm{ppm}$ at $8 \mathrm{~L}$ were used for the identification of major SMs in leaf, stem and root tissues; $800 \mu \mathrm{l}$ methanol and two glass beads were added to $30 \mathrm{mg}$ of dry biomass. The mixture was bead-beaten for $40 \mathrm{~s}$ at $6.0 \mathrm{~m} \mathrm{~s}^{-1}$ with a FastPrep Instrument (MP Biomedicals, Santa Ana, USA), then vortexed and centrifuged at $13000 \mathrm{~g}$ for $5 \mathrm{~min}$. The supernatant was collected and then analysed by HPLC coupled to a mass spectrometer. Compounds were separated on a Nucleodur Sphinx RP18ec column with dimensions of $250 \times 4.6 \mathrm{~mm}$ and a particle size of $5 \mu \mathrm{m}$ (Macherey Nagel, Dueren, Germany) using an Agilent 1100 series HPLC with a flow rate of $1.0 \mathrm{ml} \mathrm{min}^{-1}$. The column temperature was maintained at $20^{\circ} \mathrm{C}$. Phenolic compounds were separated using $0.2 \%(\mathrm{v} / \mathrm{v})$ formic acid and acetonitrile as mobile phases $A$ and $B$, respectively, with the following elution profile: $0-28 \mathrm{~min}, 5-61 \% \mathrm{~B}$ in $A ; 28-30 \mathrm{~min}$ $100 \% \mathrm{~B}$; and $30-35 \mathrm{~min} 5 \% \mathrm{~B}$.

Compound detection and quantification were accomplished with an Esquire 6000 ESI iontrap mass spectrometer (Bruker Daltronics, Bremen, Germany). Flow coming from the column was diverted in a ratio of 4:1 before entering the mass spectrometer electrospray chamber. ESI-MS was operated in negative mode scanning $\mathrm{mz}^{-1}$ between 50 and 1600 with an optimal target mass of $400 \mathrm{~m} \mathrm{z}^{-1}$. The mass spectrometer was operated using the following specifications: skimmer voltage, $60 \mathrm{~V}$; capillary voltage, $4200 \mathrm{~V}$; nebulizer pressure, $35 \mathrm{psi}$; drying gas, $11 \mathrm{I} \mathrm{min}^{-1}$; gas temperature, $330^{\circ} \mathrm{C}$. Capillary exit potential was kept at $-121 \mathrm{~V}$. Compounds of leaves and stems were identified by comparing the fragmentation patterns with previously reported wheat phenolic profiles (Moheb et al., 2011; Wojakowska et al., 2013). Root compounds were identified based on profiles of benzoxazinoids in grasses (Wouters et al., 2014).

For quantification, 500 (300) $\mu \mathrm{l} 95 \%$ methanol and two glass beads were added into 50 (30) mg samples, the mixture extracted using the same procedure described above but the remaining pellet was re-extracted again. Supernatants were pooled and then analysed by 
HPLC-UV using the same chromatographic conditions as above. The UV wavelengths 240, 260, 280 and $330 \mathrm{~nm}$ were monitored. All compounds were quantified using external standard curves. Feruoylputrescine (HPC Standards GmbH, Cunnersdorf, Germany) was used to quantify ferulic acid-based compounds in leaves and stems, and also putrescinecontaining compounds in roots. Luteolin 6-C-glucoside and apigenin 6-C-glucoside (SigmaAldrich) were used to quantify luteolin-based and apigenin-based compounds in leaves, respectively. Chrysoeriol (LGC standards, Middlesex, UK) was used to quantify chrysoeriolbased and tricin-based compounds in leaves. DIMBOA-Glc and HDMBOA-Glc in roots were quantified by standards DIMBOA-Glc and HDMBOA-Glc purified from maize roots (Wouters et al., 2014). Leaf and stem compounds were quantified at a UV absorption spectrum of $330 \mathrm{~nm}$, and root compounds at $280 \mathrm{~nm}$.

\section{Elemental analysis}

$\mathrm{C}$ and $\mathrm{N}$ concentrations of tissues were determined by an elemental analyser (varioEL II). To do so, $15 \mathrm{mg}$ dry samples were weighed into tin foil, combusted and separated by specific columns, and then assessed with a thermal conductivity detector.

\section{C balance}

Tissue-specific C, NSC and SM content was calculated by multiplying tissue-specific C (Supporting Information Table S1), NSC and SM concentrations by tissue dry mass. C content in tissue-specific NSC and SM was then calculated by multiplying tissue-specific NSC and SM content by their mass proportion of C ( 0.4 for NSC and specific fraction to each compound for the different SMs (Supporting Information Table S2)). C allocation to biomass, NSC and SMs was defined as the difference in C content of whole-plant biomass, NSC and SMs between $6 \mathrm{~L}$ and $3 \mathrm{~L}$ divided by the difference in $A_{\text {cum_n }}$ between $6 \mathrm{~L}$ and $3 \mathrm{~L}$. Note that quantifying allocation to biomass requires relatively large increase in biomass; therefore, $C$ allocation between $8 \mathrm{~L}$ and $6 \mathrm{~L}$ is not reported, given that average biomass increment of low $\left[\mathrm{CO}_{2}\right]$ plants was smaller than its standard deviation within and across chambers.

When net $\mathrm{C}$ gain estimated from gas exchange exceeded the $\mathrm{C}$ that accumulated in biomass, the difference was attributed to an 'unaccounted carbon pool' (UCP). UCP was calculated by mass balance using the following equation:

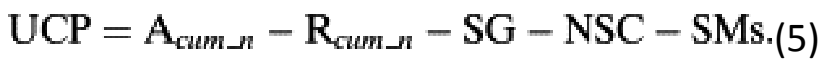

\section{Data analysis}

All of the data were analysed using Levene tests and Tukey's HSD tests that treated each growth chamber as a biological replicate $(n=3)$, to check homogeneity of variances and detect significant differences between treatments, respectively. Data were log-transformed when variance was not homoscedastic. All statistical analysis was conducted in $R$, version 3.23 (R Development Core Team, 2014). 


\section{Results}

\section{Whole-plant gas exchange and tissue biomass}

Whole-plant daily assimilation, respiration and net carbon gain increased with increasing $\left[\mathrm{CO}_{2}\right]$, but the increase was much stronger at $170 \mathrm{ppm}$ (compared to $390 \mathrm{ppm}$ ) than at 390 ppm (compared to 680 ppm) (Fig. 3a-c). However, after 9 weeks, plants grown at 390 and $680 \mathrm{ppm}$ exhibited no significant difference in day-time assimilation (A), night-time respiration $(R)$ and net carbon gain ( $A-R$; Fig. 3a-C). Initially, R/A in plants grown at 170 and $390 \mathrm{ppm}\left[\mathrm{CO}_{2}\right]$ were higher than that in plants grown at $680 \mathrm{ppm}\left[\mathrm{CO}_{2}\right]$, but the difference was not statistically significant and disappeared over time (Fig. 3d). At $3 \mathrm{~L}$, mass-based A increased with increasing $\left[\mathrm{CO}_{2}\right]$ (Fig. 4a). Mass-based R was higher at 390 and $680 \mathrm{ppm}\left[\mathrm{CO}_{2}\right]$ that at $170 \mathrm{ppm}\left[\mathrm{CO}_{2}\right]$, but there was no significant difference between the two higher $\left[\mathrm{CO}_{2}\right]$ treatments (Fig. 4b). Both mass-based $A$ and $R$ declined strongly over time at 390 and $680 \mathrm{ppm}\left[\mathrm{CO}_{2}\right]$ but much less at 170 ppm [CO $\mathrm{CO}_{2}$ (Fig. 4a,b).
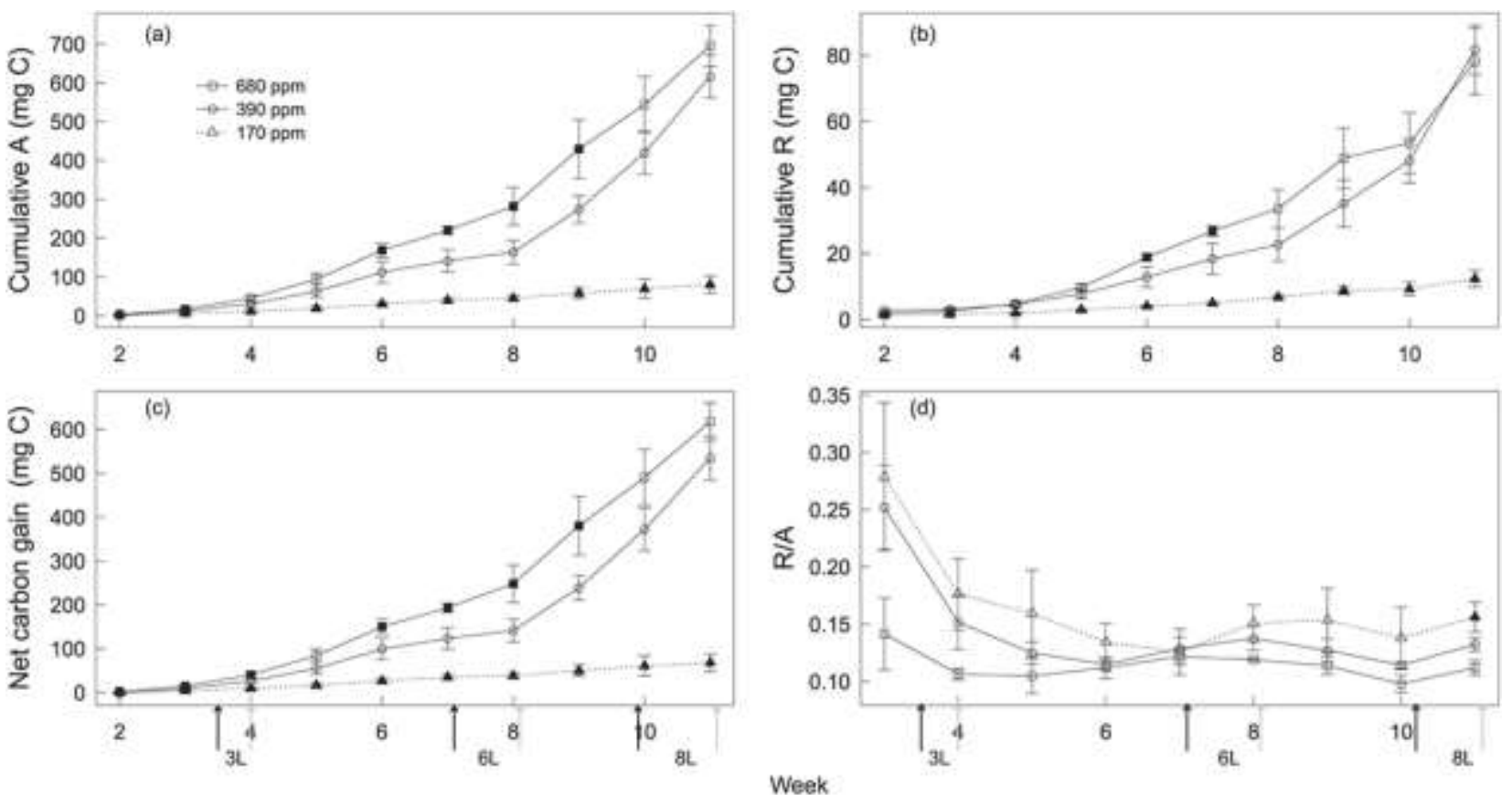

Figure 3. Weekly cumulative whole-plant net carbon assimilation $A(a)$, respiration $R(b)$, net carbon gain (c) and R/A (d) of winter wheat (Triticum aestivum cv. Genius) for the three $\left[\mathrm{CO}_{2}\right]$ treatments: $680 \mathrm{ppm}\left[\mathrm{CO}_{2}\right]$ (squares, black line); 390 ppm [CO $]$ (circles, black line); 170 ppm [CO $\mathrm{CO}_{2}$ (triangles, dashed line). Values are the means ( $\mathrm{mg} \mathrm{C}$ ) of three individual chambers; error bars represent $\pm 1 \mathrm{SD}$. Black arrows indicate sampling dates for 680 and 390 ppm [CO $\left.\mathrm{CO}_{2}\right]$ treatments; grey arrows indicate sampling dates for $170 \mathrm{ppm}\left[\mathrm{CO}_{2}\right]$ treatment. Significant differences between 680 and $170 \mathrm{ppm}\left[\mathrm{CO}_{2}\right]$ treatments compared to ambient $\left[\mathrm{CO}_{2}\right](390 \mathrm{ppm})$ are indicated by filling of symbols $(P<0.05$, Tukey's HSD). Harvests were carried out after emergence of three, six and eight leaf sheaths; denoted as $3 \mathrm{~L}, 6 \mathrm{~L}$ and $8 \mathrm{~L}$ periods, respectively. 

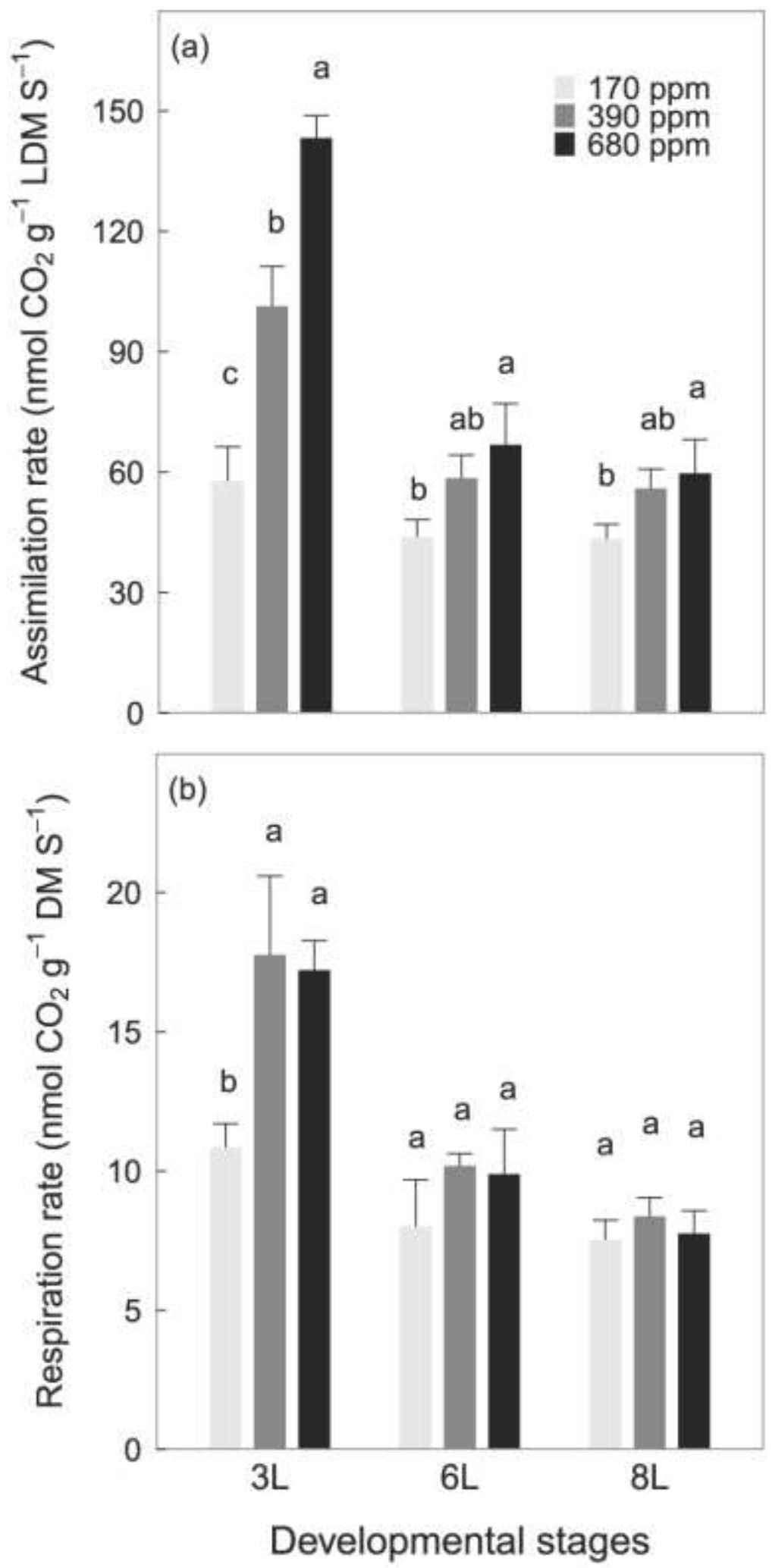

Figure 4. Leaf mass-based net assimilation rate (a) and whole-plant mass-based night-time respiration rate (b) of winter wheat (Triticum aestivum cv. Genius) for the three $\left[\mathrm{CO}_{2}\right]$ treatments: $680 \mathrm{ppm}\left[\mathrm{CO}_{2}\right]$ (black bars); $390 \mathrm{ppm}\left[\mathrm{CO}_{2}\right]$ (dark grey bars); $170 \mathrm{ppm}\left[\mathrm{CO}_{2}\right]$ (light grey bars). Values are the means $\left(\mathrm{nmol} \mathrm{CO} \mathrm{g} \mathrm{g}^{-1} \mathrm{~s}^{-1}\right.$ ) of three individual chambers; error bars represent \pm 1 SD. Different letters indicate significant differences between $\left[\mathrm{CO}_{2}\right]$ treatments $(P<0.05$, Tukey's HSD). Harvests were carried out after emergence of three, six and eight leaf sheaths; denoted as $3 \mathrm{~L}, 6 \mathrm{~L}$ and $8 \mathrm{~L}$ periods, respectively. 
Biomass varied with $\left[\mathrm{CO}_{2}\right]$ in a way similar to whole-plant assimilation and respiration. At $3 \mathrm{~L}$ and $6 \mathrm{~L}$, the dry mass of all tissues increased with increasing $\left[\mathrm{CO}_{2}\right]$, and the increase was much greater comparing plants grown between 170 and 390 ppm than between 390 and 680 ppm (Fig. 5a-d). However, at $8 \mathrm{~L}$, there was no significant difference in all tissues between 390 and 680 ppm [ $\left[\mathrm{CO}_{2}\right]$ treatments (Fig. $5 \mathrm{a}-\mathrm{d}$ ).
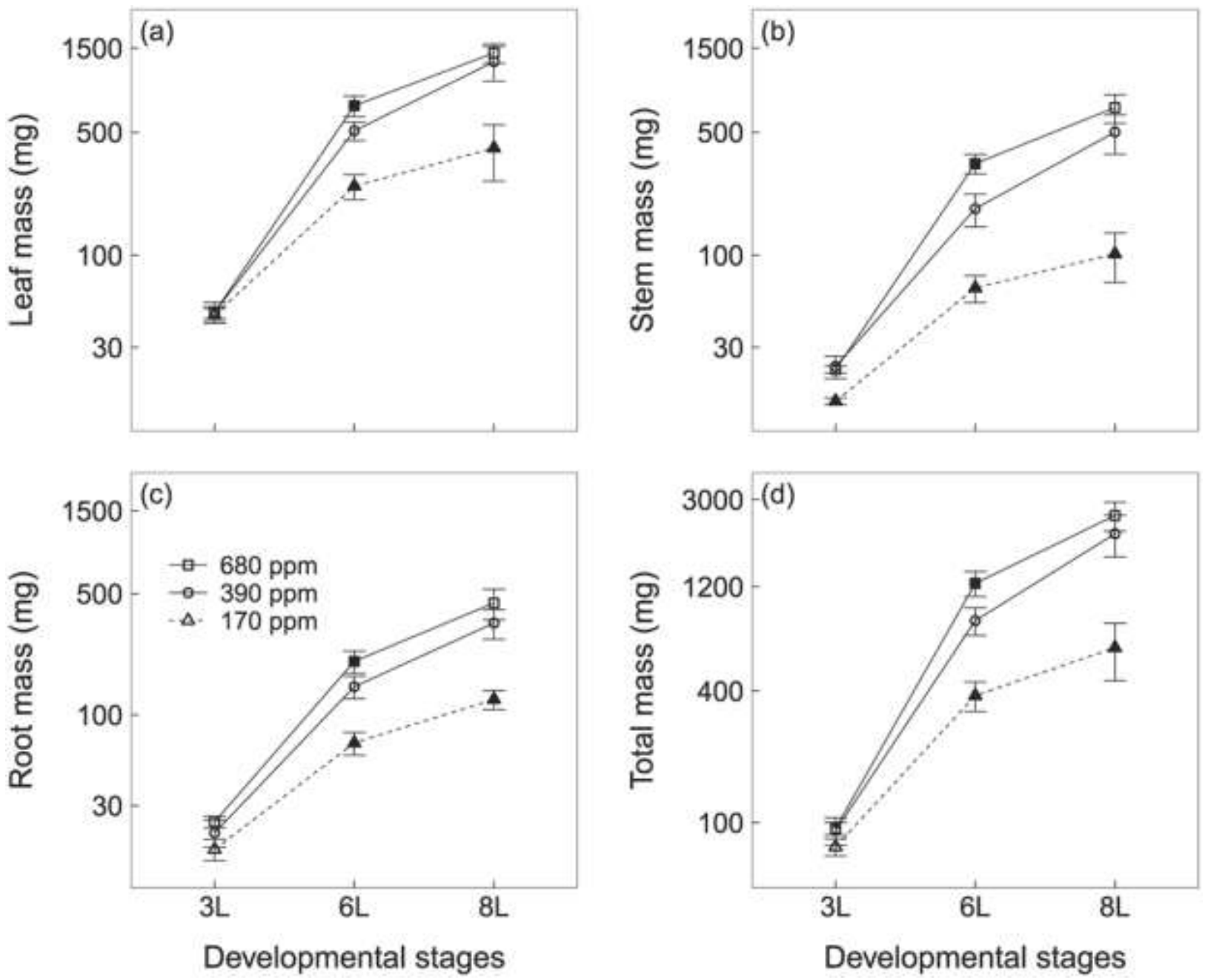

Figure 5. The dry mass of leaf (a), stem (b), root (c) and total mass (d) of winter wheat (Triticum aestivum cv. Genius) for the three $\left[\mathrm{CO}_{2}\right]$ treatments: $680 \mathrm{ppm}\left[\mathrm{CO}_{2}\right]$ (squares, black line); 390 ppm [ $\left.\mathrm{CO}_{2}\right]$ (circles, black line); $170 \mathrm{ppm}\left[\mathrm{CO}_{2}\right]$ (triangles, dashed line). Values are the means $(\mathrm{mg})$ of three individual chambers; error bars represent $\pm 1 \mathrm{SD}$. Significant differences between 680 and $170 \mathrm{ppm}\left[\mathrm{CO}_{2}\right]$ treatments compared to ambient $\left[\mathrm{CO}_{2}\right](390 \mathrm{ppm})$ are indicated by filling of symbols $(P<0.05$, Tukey's HSD). Note the dry mass is plotted on a log scale. Harvests were carried out after emergence of three, six and eight leaf sheaths; denoted as $3 \mathrm{~L}, 6 \mathrm{~L}$ and $8 \mathrm{~L}$ periods, respectively.

\section{NSC and SMs}

The response of soluble sugars and total NSC (soluble sugars + starch + fructans) to $\left[\mathrm{CO}_{2}\right]$ differed between tissues and developmental stages. At $3 \mathrm{~L}$, plant leaves grown at $170 \mathrm{ppm}$ $\left[\mathrm{CO}_{2}\right]$ had slightly higher concentrations of soluble sugars and total NSC than plant leaves grown at $390 \mathrm{ppm}\left[\mathrm{CO}_{2}\right]$, but the opposite was observed in stems and roots (Fig. 6a-f). However, while the concentrations of soluble sugars and total NSC (soluble 
sugars + starch + fructans) remained relatively constant at $170 \mathrm{ppm}\left[\mathrm{CO}_{2}\right]$ between $3 \mathrm{~L}$ and $6 \mathrm{~L}$, they doubled at $390 \mathrm{ppm}\left[\mathrm{CO}_{2}\right]$ and increased by more than three times at $680 \mathrm{ppm}$ $\left[\mathrm{CO}_{2}\right]$ over the same period (Fig. 6a-f). Whole-plant NSC content increased in proportions that were much higher than increases in total plant biomass (Fig. 7). At $6 \mathrm{~L}$, concentrations of soluble sugars and total NSC (soluble sugars + starch + fructans) were significantly higher at $680 \mathrm{ppm}$ than at $390 \mathrm{ppm}\left[\mathrm{CO}_{2}\right]$ while the difference between 390 and $170 \mathrm{ppm}\left[\mathrm{CO}_{2}\right]$ was much smaller. Between $6 \mathrm{~L}$ and $8 \mathrm{~L}$, the concentrations of soluble sugars and total NSC (soluble sugars+ starch + fructans) increased at $390 \mathrm{ppm}\left[\mathrm{CO}_{2}\right]$ but showed a declining trend at $680 \mathrm{ppm}\left[\mathrm{CO}_{2}\right]$ (Fig. $\left.6 \mathrm{a}-\mathrm{f}\right)$.
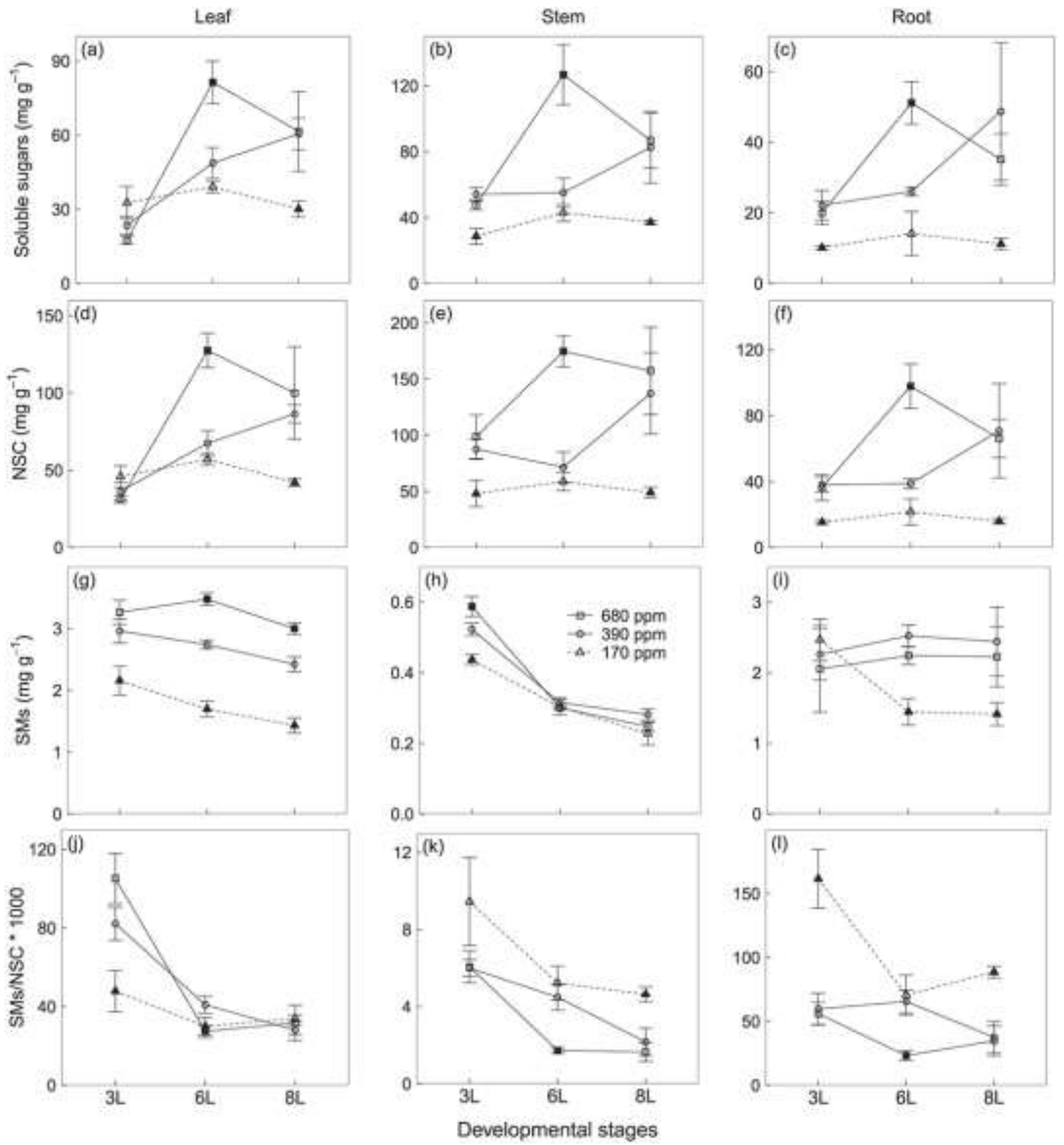

Figure 6. Concentrations of soluble sugars ( $\mathrm{mg} \mathrm{g}^{-1}$ dry weight, a-c), total non-structural carbohydrates (NSC, $\mathrm{mg} \mathrm{g}^{-1}$ dry weight, $\mathrm{d}-\mathrm{e}$ ), secondary metabolites (SMs, $\mathrm{mg} \mathrm{g}^{-1}$ dry weight, g-i) and ratios of SMs to NSC (j-I) in leaves, stems and roots of winter wheat (Triticum aestivum cv. Genius) for the three $\left[\mathrm{CO}_{2}\right]$ treatments: 680 ppm $\left[\mathrm{CO}_{2}\right]$ (squares, black line); 390 ppm [ $\left.\mathrm{CO}_{2}\right]$ (circles, black line); 170 ppm [ $\mathrm{CO}_{2}$ ] (triangles, dashed line). Total NSC concentrations were calculated as the sum of concentrations of soluble sugars, starch and fructans. Values are the means of three individual chambers; error bars represent \pm 1 SD. Significant differences 
between 680 and $170 \mathrm{ppm}\left[\mathrm{CO}_{2}\right]$ treatments compared to ambient $\left[\mathrm{CO}_{2}\right](390 \mathrm{ppm})$ are indicated by filling of symbols $(P<0.05$, Tukey's HSD). Note the different scales on $y$-axes. Harvests were carried out after emergence of three, six and eight leaf sheaths; denoted as $3 \mathrm{~L}, 6 \mathrm{~L}$ and $8 \mathrm{~L}$ periods, respectively.

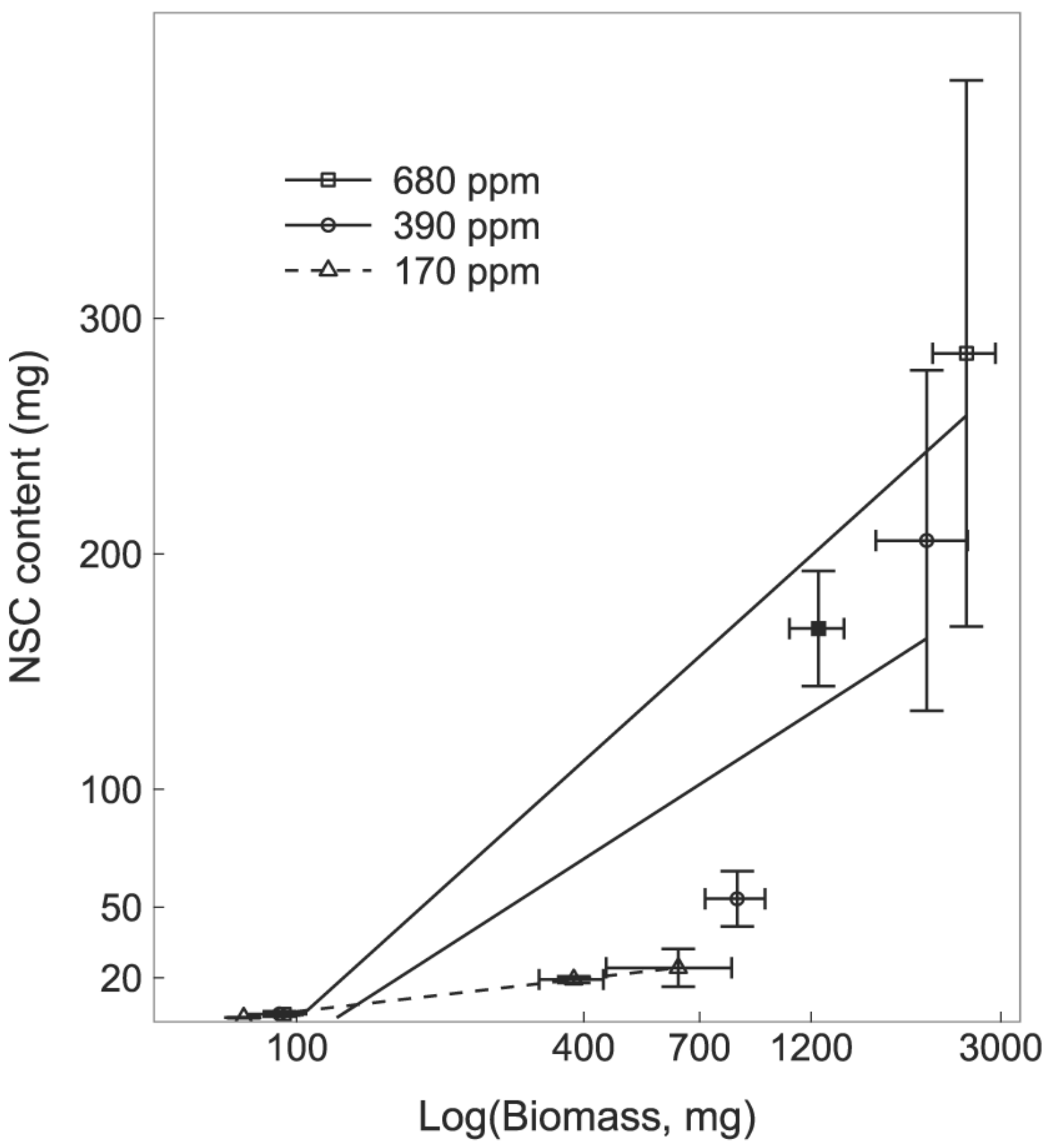

Figure 7. Correlations between whole-plant nonstructural carbohydrates (NSC) content and biomass in winter wheat (Triticum aestivum cv. Genius) for the three $\left[\mathrm{CO}_{2}\right]$ treatments: $680 \mathrm{ppm}\left[\mathrm{CO}_{2}\right]$ (squares, black line); $390 \mathrm{ppm}\left[\mathrm{CO}_{2}\right]$ (circles, black line); $170 \mathrm{ppm}\left[\mathrm{CO}_{2}\right]$ (triangles, dashed line). Values are the means ( $\mathrm{mg}$ ) of three individual chambers; error bars represent \pm 1 SD. Note the dry mass is plotted on a log scale. Significant differences in NSC content and biomass between 680 and $170 \mathrm{ppm}\left[\mathrm{CO}_{2}\right]$ treatments compared to ambient $\left[\mathrm{CO}_{2}\right](390 \mathrm{ppm})$ are indicated by filling of symbols $(P<0.05$, Tukey's HSD).

SM concentrations were much higher in leaves and roots than that in stems (Fig. 6g-i). Leaf $\mathrm{SM}$ concentrations significantly increased with increasing $\left[\mathrm{CO}_{2}\right]$ over all developmental stages (Fig. 6g). At $3 \mathrm{~L}$, stem SM concentrations significantly increased with increasing $\left[\mathrm{CO}_{2}\right]$, 
but at $6 \mathrm{~L}$ and $8 \mathrm{~L}$ there was no significant difference across $\left[\mathrm{CO}_{2}\right]$ treatments (Fig. $6 \mathrm{~h}$ ). At $6 \mathrm{~L}$ and $8 \mathrm{~L}$, root $S M$ concentrations were significantly lower at $170 \mathrm{ppm}$ than at $390 \mathrm{ppm}\left[\mathrm{CO}_{2}\right]$. By contrast, root SM concentrations were slightly higher at $390 \mathrm{ppm}$ than at $680 \mathrm{ppm}\left[\mathrm{CO}_{2}\right]$, although this difference was statistically not significant (Fig. 6i). Note that most leaf SMs are C-based compounds whereas most root SMs contain N (Supporting Information Figs S1 \& S2). Within leaves, low $\left[\mathrm{CO}_{2}\right]$ tended to decrease the concentrations of Luteolin-based, chrysoeriol-based, tricin-based and apigenin-based SMs, rather than ferulic acid-based SMs (Supporting Information Fig. S1). In addition, the concentrations of ferulic acid-based, luteolin-based and chrysoeriol-based SMs decreased from $3 \mathrm{~L}$ to $8 \mathrm{~L}$ across all $\left[\mathrm{CO}_{2}\right]$ treatments, whereas tricin-based and apigenin-based SMs increased at $680 \mathrm{ppm}\left[\mathrm{CO}_{2}\right]$ but remained relatively constant at 390 and $170 \mathrm{ppm}\left[\mathrm{CO}_{2}\right]$ (Supporting Information Fig. S1). Within roots, low $\left[\mathrm{CO}_{2}\right]$ tended to decrease DIMBOA-GIc (38\%) more than HDMBOA-Glc (25\%) (Supporting Information Fig. S2).

The response of SMs/NSC to $\left[\mathrm{CO}_{2}\right]$ differed between tissues and developmental stages (Fig. $6 \mathrm{j}-\mathrm{I}$ ). At $3 \mathrm{~L}$ and $6 \mathrm{~L}$, leaf SMs/NSC was lower at $170 \mathrm{ppm}\left[\mathrm{CO}_{2}\right]$ than at $390 \mathrm{ppm}\left[\mathrm{CO}_{2}\right]$, but at $8 \mathrm{~L}$ there was no difference in leaf SMs/NSC across $\left[\mathrm{CO}_{2}\right]$ treatments (Fig. $6 \mathrm{j}$ ). By contrast, stem and root SMs/NSC was higher at $170 \mathrm{ppm}$ than at 390 and $680 \mathrm{ppm}\left[\mathrm{CO}_{2}\right]$ (Fig. 6k,l).

\section{Proportional C allocation to respiration, structural growth, NSC and SMs}

Proportional $\mathrm{C}$ allocation to $\mathrm{R}(\mathrm{R} / \mathrm{A})$ remained relatively constant across $\left[\mathrm{CO}_{2}\right]$ treatments (Fig. 8). The proportion of $\mathrm{C}$ allocation to biomass (SG + NSC $+\mathrm{SMs}$ ) was lower in plants grown at $170 \mathrm{ppm}\left[\mathrm{CO}_{2}\right]$ than at $680 \mathrm{ppm}\left[\mathrm{CO}_{2}\right]$, although this was not statistically significant (Fig. 8). Proportional C allocation to NSC was significantly higher in plants grown at $680 \mathrm{ppm}$ than at 390 and $170 \mathrm{ppm}\left[\mathrm{CO}_{2}\right]$, and proportional $\mathrm{C}$ allocation to SMs significantly increased with increasing $\left[\mathrm{CO}_{2}\right]$ (Fig. 8). The unaccounted C pool (A - R - SG - NSC - SMs) showed large variations and no discernible trend with $\left[\mathrm{CO}_{2}\right]$.

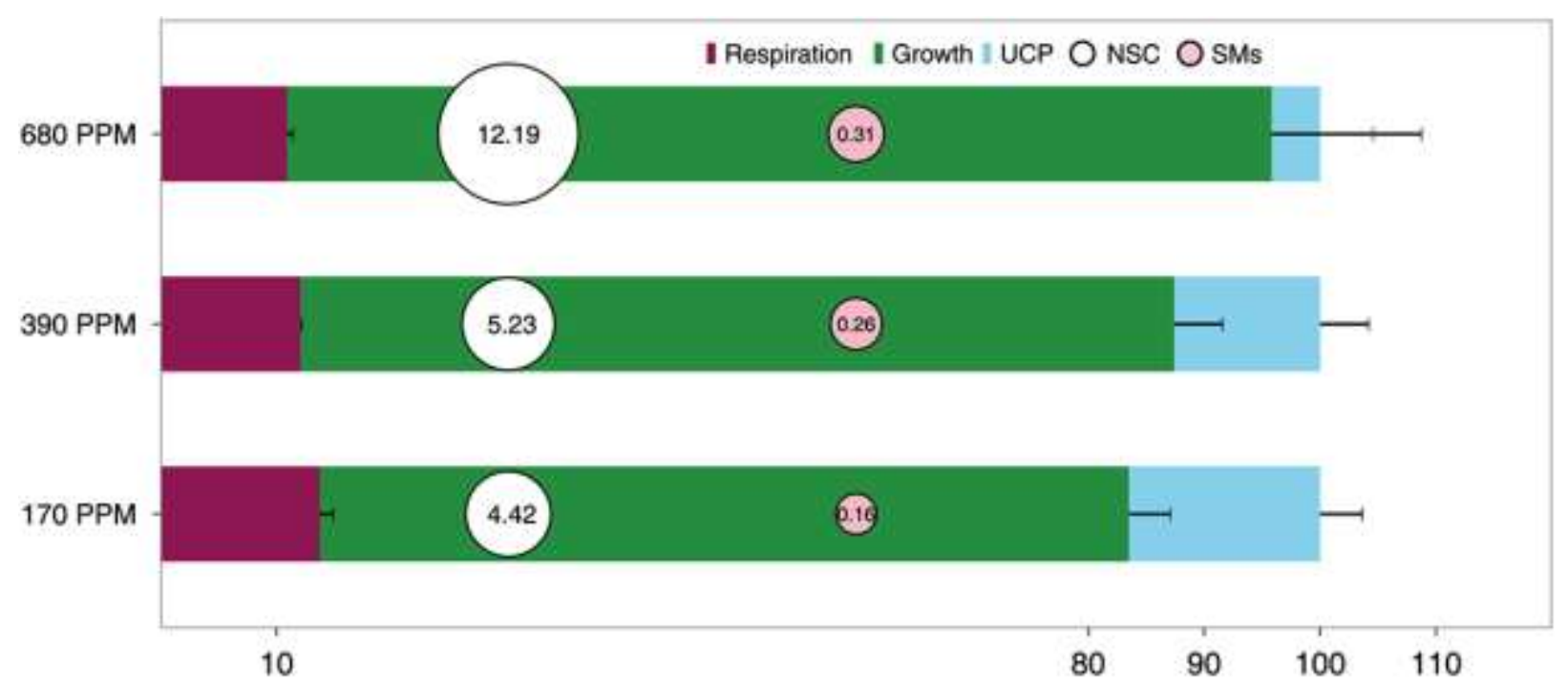

Figure 8. Percentage proportions of cumulative net carbon assimilation between $3 \mathrm{~L}$ and $6 \mathrm{~L}$ allocated to respiration (violet bars), growth (green bars), unaccounted carbon pool (UCP, blue bars), total nonstructural 
carbohydrates (NSC, white bubbles) and secondary metabolites (SMs, pink bubbles) of winter wheat (Triticum aestivum cv. Genius) for the three $\left[\mathrm{CO}_{2}\right]$ treatments: $680 \mathrm{ppm}\left[\mathrm{CO}_{2}\right] ; 390 \mathrm{ppm}\left[\mathrm{CO}_{2}\right] ; 170 \mathrm{ppm}\left[\mathrm{CO}_{2}\right]$. All concentration data were scaled up to whole-plant content by multiplying them with tissue dry mass, and then converted to carbon content before calculating proportions. The numbers in the white and pink bubbles indicate the percentage of net carbon assimilation allocated to NSC and SMs, respectively. Note, however, that the size of these bubbles has been adjusted to allow numbers to be printed and is not linearly related to the pool sizes. Values are means of three individual chambers; error bars represent $\pm 1 \mathrm{SE}$.

\section{Within-plant partitioning of biomass, NSC and SMs}

Allocation of total plant biomass and NSC to leaves, stems and roots differed with $\left[\mathrm{CO}_{2}\right]$ (Fig. 9a-f). With increasing $\left[\mathrm{CO}_{2}\right]$, allocation of biomass and NSC to leaves decreased but allocation to stems and roots increased (Fig. 9a-f). However, allocation of SMs was not affected by $\left[\mathrm{CO}_{2}\right]$; plants in all treatments showed the highest proportions in leaves and the lowest proportions in stems (Fig. 9g-i).
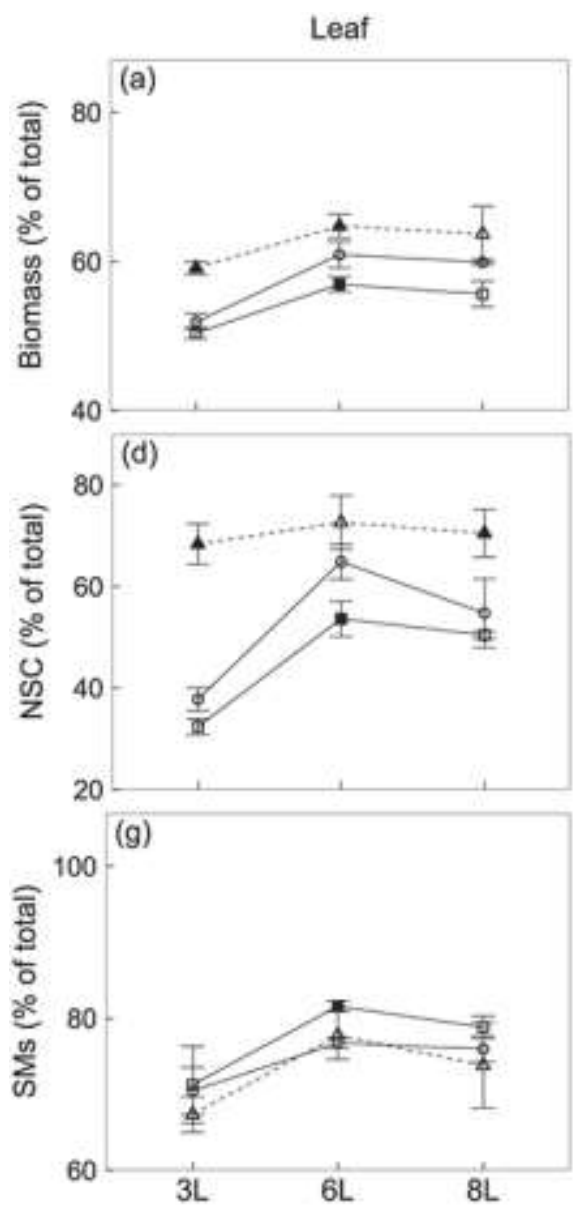

Stem
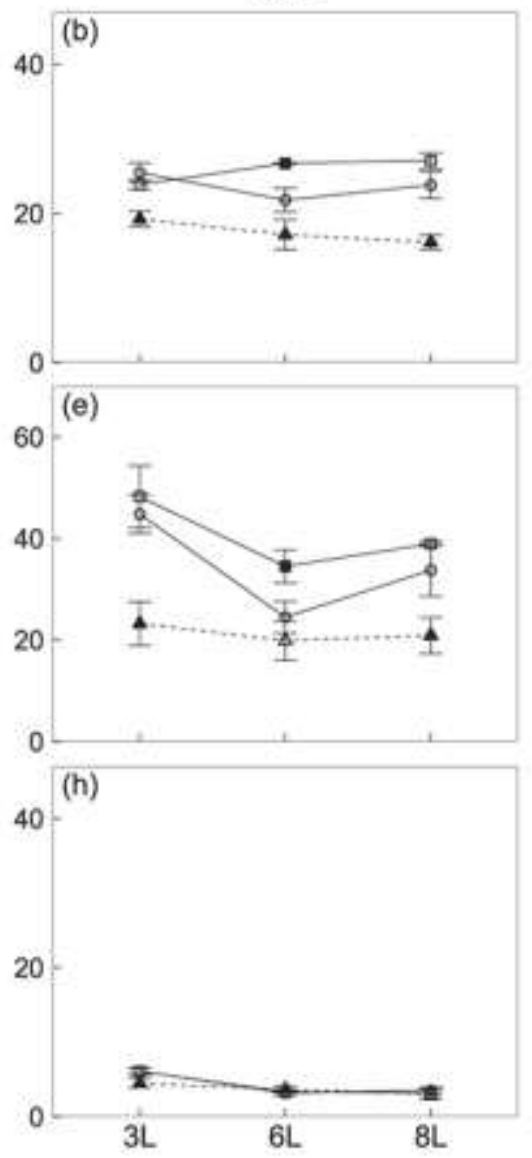

Developmental stages
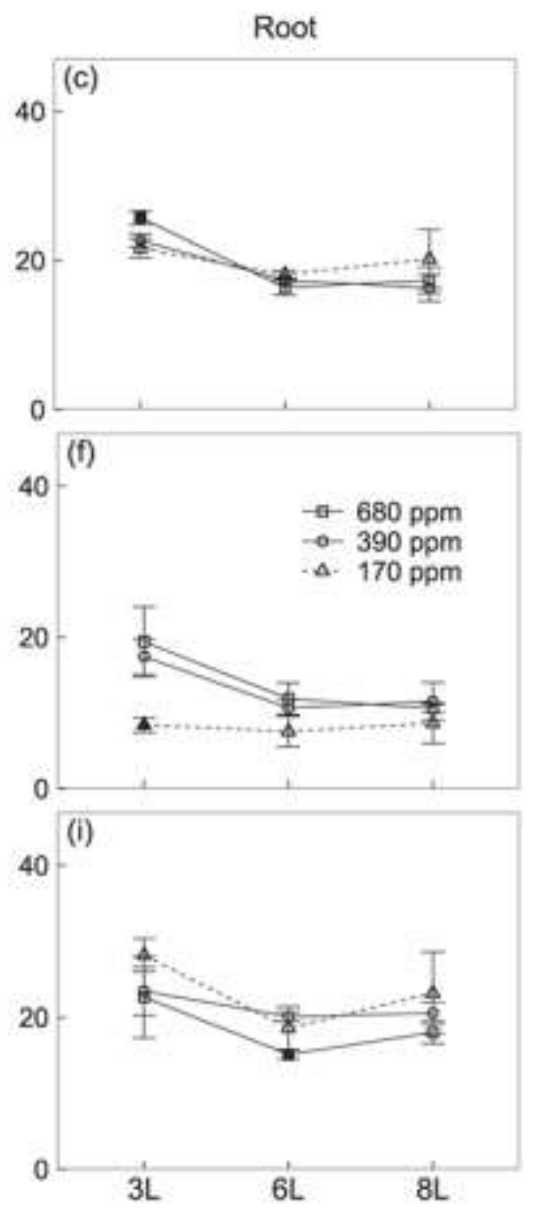

Figure 9. Percentage proportion of biomass $(a-c)$, non-structural carbohydrates (NSC, d-e) and secondary metabolites (SMs, g-i) allocated to leaves, stems and roots of winter wheat (Triticum aestivum cv. Genius) for the three $\left[\mathrm{CO}_{2}\right]$ treatments: 680 ppm [ $\left.\mathrm{CO}_{2}\right]$ (squares, black line); 390 ppm [ $\left.\mathrm{CO}_{2}\right]$ (circles, black line); 170 ppm $\left[\mathrm{CO}_{2}\right]$ (triangles, dashed line). Values are the means of three individual chambers; error bars represent \pm 1 SD. Significant differences between 680 and $170 \mathrm{ppm}\left[\mathrm{CO}_{2}\right]$ treatments compared to ambient $\left[\mathrm{CO}_{2}\right](390 \mathrm{ppm})$ are indicated by filled symbols $(P<0.05$, Tukey's HSD). Note the different scales on $y$-axes. Harvests were carried out after emergence of three, six and eight leaf sheaths; denoted as $3 \mathrm{~L}, 6 \mathrm{~L}$ and $8 \mathrm{~L}$ periods, respectively. 


\section{Discussion}

Continuous measurements of gas exchange combined with the recurrent quantification of whole-plant NSC and SMs allowed us to track C fluxes to different plant organs and functional pools. Manipulations of the whole-plant $C$ balance provided insights into the response of plant $C$ allocation to changes in $C$ availability. Our study revealed that $C$ allocation to respiration is maintained as a fixed proportion of net plant $\mathrm{C}$ gain, even over a large gradient of $\left[\mathrm{CO}_{2}\right]$. With increasing $\mathrm{C}$ availability, the fraction of assimilation allocated to biomass (SG + NSC + SMs), in particular NSC and SMs, increased. Moreover, biomass and NSC increased more in stems and roots than in leaves with increasing $C$ availability. However, under low $C$ availability resource constraints favoured the establishment of a functional equilibrium, that is, biomass and NSC increased in leaves, the tissue responsible for the acquisition of the most limiting resource, $\mathrm{CO}_{2}$. Increasing $\mathrm{C}$ availability released this constraint and allowed plants to invest proportionally more C into NSC and SMs.

\section{Minimizing carbon loss - with increasing C availability the proportion of $C$ in biomass (in particular nonstructural components) increases but respiration does not}

The higher relative allocation to respiration in the first weeks of the experiment (until $3 \mathrm{~L}$ ) in the two lower $\left[\mathrm{CO}_{2}\right]$ treatments may be due to relatively greater carbon supply from seed storage than from photosynthesis. Because seed storage ( $46 \mathrm{mg}$ seed mass on average) was depleted rapidly over time, as indicated by strong increases in plant dry biomass (ca. 230 and $1150 \mathrm{mg}$ at $3 \mathrm{~L}$ and $6 \mathrm{~L}$ at low $\left.\left[\mathrm{CO}_{2}\right]\right), \mathrm{R} / \mathrm{A}$ decreased dramatically at low and ambient $\left[\mathrm{CO}_{2}\right]$ while it remained quite constant at elevated $\left[\mathrm{CO}_{2}\right]$. Whole-plant R/A remained relatively constant across $\left[\mathrm{CO}_{2}\right]$ treatments afterwards, corroborating previously observed homeostasis of leaf-level $\mathrm{R} / \mathrm{A}$ in response to changing $\left[\mathrm{CO}_{2}\right]$ in Eucalyptus saligna (Ayub et al., 2011), G. max (Ayub et al., 2014) and wheat (Gifford, 1995). The homeostasis of whole-plant R/A was also observed across a range of temperatures in two Plantago species (Atkin et al., 2007) and at different irradiance levels in five herbaceous species (Pons \& Poorter, 2014). However, all these studies assessed gas exchange during several hours or up to few days only, and hence our study, spanning many weeks, provides further insights into long-term responses of $\mathrm{R} / \mathrm{A}$ to changes in $\left[\mathrm{CO}_{2}\right]$. Note that our estimates of the R/A ratio (ca. 10-14\%) were based on night-time respiration (R) and daytime net photosynthesis (i.e. $A=$ gross photosynthesis - daytime respiration), not on total respiration and gross photosynthesis as in other studies. Assuming daytime respiration rates equal those measured at night, the ratio of total respiration to gross photosynthesis would be $\sim 30 \%$ and within the range of proportions previously reported (ca. 30-50\%) (Atkin et al., 2007; Gifford, 1995; Pons \& Poorter, 2014).

Whole-plant assimilation and respiration are largely dependent on plant size and, therefore, do not represent photosynthetic or respiratory efficiency. By contrast, mass-based rates can indicate whether other factors than $\mathrm{CO}_{2}$ availability, like leaf $\mathrm{N}$ or sugar concentrations, may constrain assimilation or respiration. Leaf mass-based net day-time assimilation declined over time and correlated negatively with leaf NSC concentrations but positively with leaf N concentrations in all $\left[\mathrm{CO}_{2}\right]$ treatments (Supporting Information Figs S3 \& S4). Moreover, it decreased to a greater extent at elevated $\left[\mathrm{CO}_{2}\right]$ than at low $\left[\mathrm{CO}_{2}\right]$ as leaf NSC increased and 
$\mathrm{N}$ concentrations decreased to a greater extent at elevated $\left[\mathrm{CO}_{2}\right]$. These findings support previously reported sugar- (reviewed in Long et al., 2004) and Rubisco-mediated (Aranjuelo et al., 2011; Pinto et al., 2014) photosynthetic regulation under elevated $\left[\mathrm{CO}_{2}\right]$ but may also indicate proportionally greater light limitation at elevated than at low $\left[\mathrm{CO}_{2}\right]$ in the growth chambers.

The tight coupling between assimilation and respiration across $\left[\mathrm{CO}_{2}\right]$ treatments suggests that a large proportion of respiration serves to provide energy required during assimilation, for example, for processes like sucrose synthesis and phloem loading (Crous et al., 2011). However, assimilation was not the only factor influencing respiration. In absence of assimilation, that is, during nights, respiration rates were quite low, but these may have been the result of low night-time temperatures in the greenhouse. The negative correlation between mass-based night-time respiration and whole-plant NSC concentrations (Supporting Information Fig. S3) indicates that substrate supply, at least at ambient and elevated $\left[\mathrm{CO}_{2}\right]$, was not a limiting factor for respiration.

Interestingly and contrary to our expectations, plants grown at high $\left[\mathrm{CO}_{2}\right]$ invested relatively more $\mathrm{C}$ in biomass (in particular in NSC and SMs) than plants grown at low $\left[\mathrm{CO}_{2}\right]$. In these plants, a down-regulation of growth via modulation of phytohormones under stress (Achard et al., 2006; Park et al., 2007; Zhang et al., 2009) could provide an explanation for the different allocation patterns. By contrast, at elevated $\left[\mathrm{CO}_{2}\right]$, photosynthesis was apparently light-, not C-limited, and plants tended to utilize more $\mathrm{C}$ for biomass. This is consistent with the growth rate hypothesis (Coley et al., 1985; Endara \& Coley, 2011) stating that plants in resource-rich environments generally grow faster in order to be able to compete for other resources such as water, nutrients or, as in our study, for light. Greenhouse light intensities were much lower than those occurring in the field. While this may put an upper limit on absolute resource fluxes, the general agreement of allocation patterns in our study with those observed in field-grown plants downplays the impact of greenhouse light limitation on allocation patterns.

The unaccounted $C$ pool showed relatively large variations across treatments, which may be attributed, at least partially, to changes in C export, like root exudation or the emission of VOCs. Plants release root exudates as a means to facilitate organic matter decomposition presumably for nutrient acquisition, and several studies found that root exudation was much lower in plants grown at ambient than at elevated $\left[\mathrm{CO}_{2}\right]$ (Johansson et al., 2009; Phillips et al., 2009). In our experiment, nutrients were provided and freely accessible (sand and nutrient solution) thus making nutrient uptake facilitation unnecessary. However, other studies showed that plants subjected to low $\left[\mathrm{CO}_{2}\right]$ always exhibited higher emissions of VOCs (Possell \& Hewitt, 2011; Wilkinson et al., 2009), likely for quenching reactive oxygen species (Harrison et al., 2013; Loreto \& Schnitzler, 2010) that are increasingly produced during inhibition of the photosynthetic electron transfer chain under limited $\mathrm{CO}_{2}$ availability to the Calvin cycle (Brosché et al., 2010).

\section{Ensuring long-term survival - larger increases in NSC and SMs than structural growth with increasing C availability}


How plants build up NSC remains a conceptual paradigm with potentially far-reaching implications for both understanding and predicting plant responses to environmental changes (Dietze et al., 2014; Hartmann \& Trumbore, 2016). There is substantial evidence suggesting that environmental stress limits growth faster than photosynthesis thus leading to an initial excess C accumulating as NSC (Palacio et al., 2014). By contrast, trade-off allocation to NSC, that is, allocation of $\mathrm{C}$ to storage at the cost of growth, was directly assessed only in few recent studies (Gibon et al., 2009; Hartmann et al., 2015; Wiley et al., 2013) but may represent an important insurance strategy against potential future threats like herbivory and thus promote long-term survival (Wiley \& Helliker, 2012).

As a result of positive $C$ balance between $3 \mathrm{~L}$ and $6 \mathrm{~L}$, total NSC (soluble sugars + starch + fructans) concentrations doubled at $390 \mathrm{ppm}\left[\mathrm{CO}_{2}\right]$ and increased by more than three times at $680 \mathrm{ppm}\left[\mathrm{CO}_{2}\right]$. Therefore, greater $\mathrm{C}$ availability increased total NSC concentrations and whole-plant NSC content in proportions that were much higher than increases in total plant biomass. At ambient and elevated $\left[\mathrm{CO}_{2}\right], \mathrm{SG}$ may be limited by environmental factors such as nutrients and water (Kirschbaum, 2011; Palacio et al., 2014). The much higher $\mathrm{C} / \mathrm{N}$ ratio at elevated than at ambient $\left[\mathrm{CO}_{2}\right]$ also suggests that $\mathrm{SG}$ was likely $\mathrm{N}$-, rather than $\mathrm{C}$-limited (Supporting Information Table S1). At $8 \mathrm{~L}$, the subsequent decline in NSC concentrations at elevated $\left[\mathrm{CO}_{2}\right]$ may be due to photosynthetic acclimation of wheat plants to elevated [ $\left.\mathrm{CO}_{2}\right]$ (Aranjuelo et al., 2011; Aranjuelo et al., 2015). In addition, under elevated $\left[\mathrm{CO}_{2}\right]$, the size of the $\mathrm{C}$ pool in whole-plant NSC is equivalent to twice the wholeplant daily net assimilation at $6 \mathrm{~L}(1.5$ times at $8 \mathrm{~L})$. Thus, NSC at elevated $\left[\mathrm{CO}_{2}\right]$ may represent a multiple-day buffer pool for supporting metabolic activities.

Many manipulative studies have investigated the effects of elevated $\left[\mathrm{CO}_{2}\right]$ or of shading (to reduce $C$ availability) on SMs (Lindroth, 2012), but little is known about the responses of whole-plant SMs over a large gradient of $C$ availability. Leaf SM concentrations increased with increasing $C$ availability, which is in accord with the GDBH and suggests that the SM pool is filled with $C$ that is available in excess of growth demand (Herms \& Mattson, 1992). Plants grown under low $C$ availability may gain immediate benefits by reducing $C$ investments into SMs. However, SMs can serve multiple functions, such as detoxification, primary metabolism and chemical defence (Neilson et al., 2013). Large costs needed to repair and regrow plant tissues following stress conditions such as herbivory could reduce the long-term fitness of low $\left[\mathrm{CO}_{2}\right]$ plants with low $\mathrm{SMs}$, as suggested by the growth rate hypothesis (Coley et al., 1985). In addition, plants at $3 \mathrm{~L}$ had relatively more young leaves and higher leaf and stem SMs than plants at $8 \mathrm{~L}$. Greater leaf and stem SMs in young vulnerable leaves that also have greater photosynthetic capacity may represent an investment insurance strategy.

$\mathrm{N}$-rich SMs play important roles in ecological interactions, but very few studies investigated how they may respond to elevated $\left[\mathrm{CO}_{2}\right]$ (Lindroth, 2012). As expected, low $\left[\mathrm{CO}_{2}\right]$ decreased $\mathrm{N}$-containing SMs (benzoxazinoid derivatives) in roots. This is consistent with the GDBH and suggests that limited $\mathrm{C}$ resources are preferentially invested in SG rather than SMs. Furthermore, low $\left[\mathrm{CO}_{2}\right]$ tended to decrease DIMBOA-GIc more than HDMBOA-GIc (Supporting Information Fig. S2), possibly because HDMBOA-Glc is more efficient against pathogens and insect herbivory (Glauser et al., 2011) and represents the better investment 
under $\mathrm{C}$ limitation. By contrast, concentrations of these compounds were slightly lower at elevated $\left[\mathrm{CO}_{2}\right]$ than at ambient $\left[\mathrm{CO}_{2}\right]$, likely because the production of these $\mathrm{N}$-rich SMs (putrescine-based and benzoxazinoids) may have been limited by $\mathrm{N}$ supply rather than $\mathrm{C}$ supply (Supporting Information Table S1). This interpretation is in agreement with results from other studies showing that elevated $\left[\mathrm{CO}_{2}\right]$ inhibited nitrate assimilation in wheat (Bloom et al., 2010). Given the defensive role of benzoxazinoid derivatives (Ahmad et al., 2011), the responses observed in our study support previously reported increases in egg densities of western corn rootworm (Diabrotica virgifera virgifera) in the soil of soybean fields under elevated $\left[\mathrm{CO}_{2}\right]$ (Schroeder et al., 2006).

The trade-off between allocation to NSC versus SMs was tissue specific and depended on the developmental stage of the plants. At $3 \mathrm{~L}$, leaf SMs/NSC increased with increasing $C$ availability, indicating that leaves tend to invest more NSC into SM production. By contrast, root SMs/NSC declined with increasing $\mathrm{C}$ availability, suggesting that plant roots grown at ambient and elevated $\left[\mathrm{CO}_{2}\right]$ increase NSC more than SMs, likely due to a potential $\mathrm{N}$ limitation on root SM production, as discussed above.

\section{Achieving a functional equilibrium - with increasing $C$ availability wheat plants prioritize allocation of biomass and NSC to stems and roots over leaves}

Allocation patterns of biomass and NSC are consistent with the 'functional equilibrium' hypothesis (Poorter et al., 2012). At low [ $\left.\mathrm{CO}_{2}\right]$, plants were apparently constrained to invest proportionally more biomass and NSC in leaves, while with increasing $\mathrm{C}$ availability biomass and NSC increased in stems and roots. Under low $\left[\mathrm{CO}_{2}\right]$, this optimization strategy allows plants to counteract $\mathrm{C}$ limitation, while a more balanced resource partitioning was required to support taller plants under elevated $\left[\mathrm{CO}_{2}\right]$. Moreover, export of NSC from leaves to stems and roots in plants at elevated $\left[\mathrm{CO}_{2}\right]$ may help plants to build storage and avoid high NSCinduced negative feedback on assimilation (Long et al., 2004). By contrast, proportional allocation to SMs across plant organs did not vary between treatments, likely because leaf SMs and root SMs differed in $\mathrm{C}$ and $\mathrm{N}$ cost.

\section{Outlook}

While our experimental design allowed us to quantify several functional sinks of the plant $C$ balance, it did not allow direct assessments of root exudates and VOCs and thereby prevented differentiating among $C$ exports. The high variability in the unaccounted $C$ pool in our experiment is likely due to the accumulation of uncertainties across different measurements and devices (Vaisala, Picarro, FTIR, elemental analyser, HPLC-PAD and HPLCUV). Thus, future studies would benefit from direct assessment of 'export' C fluxes, including root exudates and VOCs, while keeping in mind that very short-lived or rapidly decomposed export may be detected in experimental set-ups as respiration (i.e. $\mathrm{CO}_{2}$ ).

Given that SMs can serve multiple functions, the role of C allocation to SMs as a strategic investment for defence can only be assessed by simultaneously evaluating responses of herbivores and/or pathogens. Such studies have been conducted on soybean under elevated $\left[\mathrm{CO}_{2}\right]$ (reviewed in Zavala et al., 2013) and can guide future studies with low $\mathrm{C}$ 
availability $\left(\left[\mathrm{CO}_{2}\right]\right)$. Because our knowledge about the mechanisms controlling plant allocation is still very limited, future studies should also focus on biochemical and molecular regulation of growth (Claeys et al., 2014) and explore regulatory mechanisms of other allocation sinks like storage and SMs.

\section{Acknowledgements}

We thank Savoyane Lambert, Iris Kuhlmann and Somak Chowdhury for their help with sample processing, Ines Hilke for elemental analysis, and Michael Rässler and Jessica Heublein for measurements of sugars, starch and fructans. Jonathan Gershenzon and Michael Reichelt supported us for measurements of secondary metabolites. Waldemar Ziegler, Olaf Kolle and René Schwalbe assisted in setting up the $\left[\mathrm{CO}_{2}\right]$ manipulation. Daniel Rzesanke helped with the FTIR manipulation. We thank Susan Trumbore for helpful comments and language revision of the manuscript. J.H. was funded by Chinese Scholarship Council and Max Planck Institute.

\section{References}

Achard P., Cheng H., De Grauwe L., Decat J., Schoutteten H., Moritz T. \& Harberd N.P. (2006) Integration of plant responses to environmentally activated phytohormonal signals. Science 311, 9194.

Ahmad S., Veyrat N., Gordon-Weeks R., Zhang Y.H., Martin J., Smart L. \& Ton J. (2011) Benzoxazinoid metabolites regulate innate immunity against aphids and fungi in maize. Plant Physiology 157, 317327.

Aranjuelo I., Cabrera-Bosquet L., Morcuende R., Avice J.C., Nogués S.,Araus J.L. \& Pérez P. (2011) Does ear $C$ sink strength contribute to overcoming photosynthetic acclimation of wheat plants exposed to elevated $\mathrm{CO}_{2}$ ? Journal of Experimental Botany 62, 3957-3969.

Aranjuelo I., Erice G., Sanz-Sáez A., Abadie C., Gilard F., Gil-Quintana E. \& Tcherkez G. (2015)

Differential $\mathrm{CO}_{2}$ effect on primary carbon metabolism of flag leaves in durum wheat (Triticum durum Desf.). Plant, Cell \& Environment 38, 2780-2794.

Atkin O.K., Scheurwater I. \& Pons T.L. (2007) Respiration as a percentage of daily photosynthesis in whole plants is homeostatic at moderate, but not high, growth temperatures. New Phytologist 174, 367-380.

Ayub G., Smith R.A., TissueD.T.\&AtkinO.K. (2011) Impacts of drought on leaf respiration in darkness and light in Eucalyptus saligna exposed to industrial-age atmospheric $\mathrm{CO}_{2}$ and growth temperature. New Phytologist 190, 1003-1018.

Ayub G., Zaragoza-Castells J., Griffin K.L.\& Atkin O.K. (2014) Leaf respiration in darkness and in the light under pre-industrial, current and elevated atmospheric $\mathrm{CO}_{2}$ concentrations. Plant Science 226, 120-130.

Ballare C.L. (2014) Light regulation of plant defense. Annual Review of Plant Biology 65, 335-363. 
BekaertM., Edger P.P., Hudson C.M., Pires J.C. \& Conant G. C. (2012)Metabolic and evolutionary costs of herbivory defense: systems biology of glucosinolate synthesis. New Phytologist 196, 596605.

Bloom A.J., Burger M., Asensio J.S.R. \& Cousins A.B. (2010) Carbon dioxide enrichment inhibits nitrate assimilation in wheat and Arabidopsis. Science 328, 899-903.

Boote K.J., Jones J.W., White J.W., Asseng S. \& Lizaso J.I. (2013) Putting mechanisms into crop production models. Plant, Cell \& Environment 36, 1658-1672.

Brosché M., Overmyer K.,Wrzaczek M., Kangasjärvi J. \& Kangasjärvi S. (2010) Stress signaling III: reactive oxygen species (ROS). In Abiotic Stress Adaptation in Plants: Physiological, Molecular and Genomic Foundation (eds Pareek A., Sopory S.K. \& Bohnert J.H.), pp. 91-102. Springer Netherlands, Dordrecht.

Casal J.J. (2013) Photoreceptor signaling networks in plant responses to shade. Annual Review of Plant Biology 64, 403-427.

Chapin F.S., Schulze E.-D.\&Mooney H.A. (1990) The ecology and economics of storage in plants. Annual Review of Ecology and Systematics 21, 423-447.

Claeys H.,De Bodt S.\&Inze D. (2014) Gibberellins and DELLAs: central nodes in growth regulatory networks. Trends in Plant Science 19, 231-239.

Coley P.D., Bryant J.P. \& Chapin F.S. (1985) Resource availability and plant antiherbivore defense. Science 230, 895-899.

Crous K.Y., Zaragoza-Castells J., Löw M., Ellsworth D.S., Tissue D.T., Tjoelker M.G.\& Atkin O.K. (2011) Seasonal acclimation of leaf respiration in Eucalyptus saligna trees: impacts of elevated atmospheric CO2 and summer drought. Global Change Biology 17, 1560-1576.

Cubasch U., Wuebbles D., Chen D., Facchini M.C., Frame D., Mahowald N. \& Winther J.-G. (2013) Introduction. In Climate Change 2013: The Physical Science Basis. Contribution of Working Group I to the Fifth Assessment Report of the Intergovernmental Panel on Climate Change (eds Stocker T.F., Qin D., Plattner G.-K., Tignor M., Allen S.K., Boschung J. \& Midgley P.M.), pp. 119-158. Cambridge University Press, Cambridge, United Kingdom and New York, NY, USA.

Dietze M.C., Sala A., Carbone M.S., Czimczik C.I., Mantooth J.A., Richardson A.D. \& Vargas R. (2014) Nonstructural carbon in woody plants. Annual Review of Plant Biology 65, 667-687.

Endara M.J.\& Coley P.D. (2011) The resource availability hypothesis revisited: a meta-analysis. Functional Ecology 25, 389-398.

Fatichi S., Leuzinger S.\& Korner C. (2014) Moving beyond photosynthesis: from carbon source to sink-driven vegetation modeling. New Phytologist 201, 1086-1095.

Franks P.J., Adams M.A., Amthor J.S., Barbour M.M., Berry J.A., Ellsworth D.S. \& von Caemmerer S. (2013) Sensitivity of plants to changing atmospheric $\mathrm{CO}_{2}$ concentration: from the geological past to the next century. New Phytologist 197, 1077-1094. 
Gerhart L.M. \& Ward J.K. (2010) Plant responses to low $\left[\mathrm{CO}_{2}\right]$ of the past. New Phytologist $188,674-$ 695.

Gibon Y., Pyl E.-T., Sulpice R., Lunn J.E., Höhne M., Günther M. \& Stitt M. (2009) Adjustment of growth, starch turnover, protein content and central metabolism to a decrease of the carbon supply when Arabidopsis is grown in very short photoperiods. Plant, Cell \& Environment 32, 859-874.

Gifford R.M. (1995) Whole plant respiration and photosynthesis of wheat under increased $\mathrm{CO}_{2}$ concentration and temperature: long-term vs. short-term distinctions for modelling. Global Change Biology 1, 385-396.

Glauser G., Marti G., Villard N., Doyen G.A.,Wolfender J.-L., Turlings T.C.J. \& Erb M. (2011) Induction and detoxification of maize 1,4-benzoxazin-3-ones by insect herbivores. The Plant Journal 68, 901911.

Grayston S.J., Vaughan D. \& Jones D. (1997) Rhizosphere carbon flow in trees, in comparison with annual plants: the importance of root exudation and its impact on microbial activity and nutrient availability. Applied Soil Ecology 5, 29-56.

Halkier B.A.\& Gershenzon J. (2006) Biology and biochemistry of glucosinolates. Annual Review of Plant Biology 57, 303-333.

Harrison S.P., Morfopoulos C., Dani K.G.S., Prentice I.C.,Arneth A., Atwell B.J. \& Wright I.J. (2013) Volatile isoprenoid emissions from plastid to planet. New Phytologist 197, 49-57.

Hartmann H., McDowell N.G. \& Trumbore S. (2015) Allocation to carbon storage pools in Norway spruce saplings under drought and lowCO $\mathrm{C}_{2}$. Tree Physiology 35, 243-252.

Hartmann H. \& Trumbore S. (2016) Understanding the roles of non-structural carbohydrates in forest trees - from what we can measure to what we want to know. New Phytologist 211, 386-403.

Hartmann H., Ziegler W., Kolle O. \& Trumbore S. (2013) Thirst beats hunger - declining hydration during drought prevents carbon starvation in Norway spruce saplings. New Phytologist 200, 340349 .

Herms D.A. \& Mattson W.J. (1992) The dilemma of plants: to grow or defend. The Quarterly Review of Biology 67, 283-335.

Hoagland D.R. \& Arnon D.I. (1950) The water culture method for growing plants without soil. Calif Agric. Exp. Station Circular 347, 1-32.

Johansson E.M., Fransson P.M.A., Finlay R.D. \& van Hees P.A.W. (2009) Quantitative analysis of soluble exudates produced by ectomycorrhizal roots as a response to ambient and elevated $\mathrm{CO}_{2}$. Soil Biology and Biochemistry 41, 1111-1116.

Kirschbaum M.U.F. (2011) Does enhanced photosynthesis enhance growth? Lessons learned from $\mathrm{CO}_{2}$ enrichment studies. Plant Physiology 155, 117-124.

Korner C. (2015) Paradigm shift in plant growth control. Current Opinion in Plant Biology 25, 107114. 
Lee T.D., Barrott S.H. \& Reich P.B. (2011) Photosynthetic responses of 13 grassland species across 11 years of free-air $\mathrm{CO}_{2}$ enrichment is modest, consistent and independent of $\mathrm{N}$ supply. Global Change Biology 17, 2893-2904.

Lindroth R.L. (2012) Atmospheric change, plant secondary metabolites and ecological interactions. In Ecology of Plant SecondaryMetabolites: From Genes to Global Processes (eds lason G.R., Dicke M. \& Hartley S.E.), pp. 120-153. Cambridge University Press, Cambridge, United Kingdom and New York, NY, USA.

Long S.P., Ainsworth E.A., Rogers A. \& Ort D.R. (2004) Rising atmospheric carbon dioxide: plants face the future. Annual Review of Plant Biology 55, 591-628.

Loreto F. \& Schnitzler J.-P. (2010) Abiotic stresses and induced BVOCs. Trends in Plant Science 15, 154-166.

Moheb A., Ibrahim R.K., Roy R. \& Sarhan F. (2011) Changes in wheat leaf phenolome in response to cold acclimation. Phytochemistry 72, 2294-2307.

Mooney H.A. (1972) The carbon balance of plants. Annual Review of Ecology and Systematics 3, 315346.

Neilson E.H., Goodger J.Q.D., Woodrow I.E. \& Møller B.L. (2013) Plant chemical defense: at what cost? Trends in Plant Science 18, 250-258.

O’Neill B.F., Zangerl A.R., Dermody O., Bilgin D.D., Casteel C.L., Zavala J.A. \& Berenbaum M.R. (2010) Impact of elevated levels of atmospheric $\mathrm{CO}_{2}$ and herbivory on flavonoids of soybean (Glycine max Linnaeus). Journal of Chemical Ecology 36, 35-45.

Palacio S., Hoch G., Sala A., Körner C. \& Millard P. (2014) Does carbon storage limit tree growth? New Phytologist 201, 1096-1100.

Park J.-E., Park J.-Y., Kim Y.-S., Staswick P.E., Jeon J., Yun J. \& Park C.-M. (2007) GH3-mediated auxin homeostasis links growth regulation with stress adaptation response in Arabidopsis. Journal of Biological Chemistry 282, 10036-10046.

Phillips R.P., Bernhardt E.S. \& Schlesinger W.H. (2009) Elevated $\mathrm{CO}_{2}$ increases root exudation from loblolly pine (Pinus taeda) seedlings as an N-mediated response. Tree Physiology 29, 1513-1523.

Pinto H., Sharwood R.E., Tissue D.T. \& Ghannoum O. (2014) Photosynthesis of C-3, C-3-C-4, and C-4 grasses at glacial $\mathrm{CO}_{2}$. Journal of Experimental Botany 65, 3669-3681.

Pollock A. \& Cairns A.J. (1991) Fructan metabolism in grasses and cereals. Annual Review of Plant Physiology and Plant Molecular Biology 42, 77-101.

Pons T.L. \& Poorter H. (2014) The effect of irradiance on the carbon balance and tissue characteristics of five herbaceous species differing in shade-tolerance. Frontiers in Plant Science 5, 14. 
Poorter H., Niklas K.J., Reich P.B., Oleksyn J., Poot P. \& Mommer L. (2012) Biomass allocation to leaves, stems and roots: meta-analyses of interspecific variation and environmental control. New Phytologist 193, 30-50.

Possell M. \& Hewitt C.N. (2011) Isoprene emissions from plants are mediated by atmospheric $\mathrm{CO}_{2}$ concentrations. Global Change Biology 17, 1595-1610.

R Development Core Team (2014) R: a language and environment for statistical computing. $R$ foundation for Statistical computing, URL http://www.r-project.org., Vienna, Austria.

Raessler M., Wissuwa B., Breul A., Unger W. \& Grimm T. (2010) Chromatographic analysis of major non-structural carbohydrates in several wood species - an analytical approach for higher accuracy of data. Analytical Methods 2, 532-538.

Robinson E.A., Ryan G.D. \& Newman J.A. (2012) A meta-analytical review of the effects of elevated $\mathrm{CO}_{2}$ on plant-arthropod interactions highlights the importance of interacting environmental and biological variables. New Phytologist 194, 321-336.

Schnyder H. (1992) Long-term steady-state labelling of wheat plants by use of natural ${ }^{13} \mathrm{CO}_{2} /{ }^{12} \mathrm{CO}_{2}$ mixtures in an open, rapidly turned-over system. Planta 187, 128-135.

Schroeder J.B., Gray M.E., Ratcliffe S.T., Estes R.E. \& Long S.P. (2006) Effects of elevated $\mathrm{CO}_{2}$ and $\mathrm{O}_{3}$ on a variant of the western corn rootworm (Coleoptera: Chrysomelidae). Environmental Entomology $35,637-644$.

Sullivan J.T. (1935) The estimation of starch. Industrial \& Engineering Chemistry Analytical Edition 7, 311-314.

Temme A.A., Cornwell W.K., Cornelissen J.H.C. \& Aerts R. (2013) Metaanalysis reveals profound responses of plant traits to glacial $\mathrm{CO}_{2}$ levels. Ecology and Evolution 3, 4525-4535.

Tissue D.T. \& Lewis J.D. (2012) Learning from the past: how low $\left[\mathrm{CO}_{2}\right]$ studies inform plant and ecosystem response to future climate change. New Phytologist 194, 4-6.

Wiley E. \& Helliker B. (2012) A re-evaluation of carbon storage in trees lends greater support for carbon limitation to growth. New Phytologist 195, 285-289.

Wiley E., Huepenbecker S., Casper B.B. \& Helliker B.R. (2013) The effects of defoliation on carbon allocation: can carbon limitation reduce growth in favour of storage? Tree Physiology 33, 1216-1228. 